\title{
Study of Iron Piperazine-Based Chelators as Potential Siderophore Mimetics
}

\author{
Pauline Loupias ${ }^{1}$, Isabelle Dechamps-Olivier ${ }^{2}$, Laurent Dupont ${ }^{2}$, Pierre Vanlemmens ${ }^{1}$, \\ Catherine Mullié ${ }^{1}{ }^{\circledR}$, Nicolas Taudon ${ }^{3}$, Anne Bouchut ${ }^{1}$, Alexandra Dassonville-Klimpt ${ }^{1}$ and \\ Pascal Sonnet ${ }^{1, * \text { iD }}$ \\ 1 AGIR, EA 4294, UFR de Pharmacie, Université de Picardie Jules Verne, 1 rue des Louvels, 80037 Amiens, \\ France; pauline.loupias@etud.u-picardie.fr (P.L.); pierre.vanlemmens@u-picardie.fr (P.V.); \\ catherine.mullie@u-picardie.fr (C.M.); anne.bouchut@sattnord.fr (A.B.); \\ alexandra.dassonville@u-picardie.fr (A.D.-K.) \\ 2 ICMR, UMR 7312, 3 Avenue du Maréchal Juin, 51100 Reims, France; \\ isabelle.dechamps@univ-reims.fr (I.D.-O.); laurent.dupont@univ-reims.fr (L.D.) \\ 3 Unité de Toxicologie Analytique, Institut de Recherche Biomédicales des Armées, 91223 Brétigny-sur-Orge, \\ France; nicolas.taudon@gmail.com \\ * Correspondence: pascal.sonnet@u-picardie.fr
}

Received: 20 September 2019; Accepted: 22 October 2019; Published: 23 October 2019

\begin{abstract}
Gram-negative bacteria's resistance such as Pseudomonas aeruginosa and the Burkholderia group to conventional antibiotics leads to therapeutic failure. Use of siderophores as Trojan horses to internalize antibacterial agents or toxic metals within bacteria is a promising strategy to overcome resistance phenomenon. To combat the Pseudomonas sp, we have synthesized and studied two piperazine-based siderophore mimetics carrying either catecholate moieties (1) or hydroxypyridinone groups (2) as iron chelators. These siderophore-like molecules were prepared in no more than four steps with good global yields. The physicochemical study has highlighted a strong iron affinity since their $\mathrm{pFe}$ values were higher than 20.1 possesses even a $\mathrm{pFe}$ value superior than those of pyoverdine, the $P$. aeruginosa endogenous siderophore, suggesting its potential ability to compete with it. At physiological $\mathrm{pH}, \mathbf{1}$ forms mainly a 2:3 complex with iron, whereas two species are observed for $\mathbf{2}$. Unfortunately, the corresponding Ga(III)-1 and $\mathbf{2}$ complexes showed no antibacterial activity against P. aeruginosa DSM 1117 strain. The evaluation of their siderophore-like activity showed that $\mathbf{1}$ and $\mathbf{2}$ could be internalized by the bacteria.
\end{abstract}

Keywords: Pseudomonas group; siderophore mimetics; chelators; iron; piperazine

\section{Introduction}

Among Gram-negative bacteria, Pseudomonas aeruginosa and Burkholderia pseudomallei are particularly worrying. $P$. aeruginosa is often involved in nosocomial infections $(6.2 \%$ of all hospital-acquired infections) [1,2]. B. pseudomallei, formerly classified as P. pseudomallei, causes melioidosis (Whitmore disease) which prevails in tropical climates. Cases were also reported in the U.S. [3,4]. The most common form of this disease, pulmonary melioidosis, resembles to tuberculosis and is particularly recalcitrant to therapy with a high relapse rate [5]. The research team, AGIR, is implicated in the development of new ways to combat Gram-negative bacteria. In particular, the Pseudomonas group is targeted due to its resistance to antibiotics via a lack of membrane permeability or efflux, leading to therapeutic failure and requires new antibiotic therapies.

Using iron transport systems is a promising strategy to overcome the lack of membrane permeability by restoring the activity of conventional antibiotics [6,7]. Iron is an essential metal 
for, playing key structural and chemical roles in protein cofactors (heme and Fe-S clusters) [8]. The insolubility of the ferric ion under biological conditions $\left(10^{-18} \mathrm{M}\right.$ at neutral $\left.\mathrm{pH}\right)$ makes it a vital nutriment in cellular homeostasis. During the infectioN's establishment, the situation is exacerbated because serum proteins and the liver sequestrate the free Fe(III) [9]. In an effort to scavenge iron from both natural environmental and infection settings, bacteria have developed pathways to synthesize, secrete, and retrieve small molecule chelators called siderophores [10]. These chelators display a very high affinity for ferric iron which can be measured by the $\mathrm{pFe}$ value under physiological conditions. The $\mathrm{pFe}$ is the negative logarithm of the free ferric iron in solution at $\mathrm{pH} 7.4$ for defined concentration of ligand $\left(10^{-5} \mathrm{M}\right)$ and iron $\left(10^{-6} \mathrm{M}\right)[11,12]$. This very high affinity for ferric irons enables siderophores to drive the dissolution of insoluble salts in the environment or to strip off ferric iron from host sequestering proteins. Depending on their chemical functional groups, siderophores can be divided into three main groups: (i) catecholates or phenolates as enterobactin, (ii) hydroxamates as deferoxamine (DFO), and (iii) $\alpha$-hydroxycarboxylates as staphyloferrin A. Most often, the same oxygen-donor group is represented two or three-fold into linear or cyclic platforms to form tetradentate (3:2/siderophore-Fe(III) complexes) or hexadentate ligands (1:1/siderophore-Fe(III) complexes). They can also be mixed in pyoverdine ( $\mathrm{Pvd}$ ) or pyochelin (Pch), the two main siderophores of Pseudomonas [13]. Each bacterium possesses its own outer membrane receptor (OMR), specific to each siderophore. This way, they can uptake siderophores produced by other species. P. aeruginosa secures its iron acquisition by internalization of Pvd and Pch, recognized respectively by the FpvA (or FpvB) and FptA [14]. This strain is also able to use exogenous iron chelators through the expression of different OMRs such as FecA (for ferric citrate), PfeA and PirA (for enterobactin), FoxA and FiuA (for DFO and ferrichrome), FemA (for mycobactin) and ChtA (for rhizobactin and aerobactin) [6].

These OMRs are different entry routes for toxic complexes and antibiotics using the "Trojan Horse Strategy". These two concepts were reported in the antipseudomonal strategy. In 2008, DFO-Ga(III) complex was described as a potential therapeutic agent against $P$. aeruginosa [15]. More recently, the great activities of two siderophore-antibiotic conjugates, BAL 30,072 [16-19] and cefiderocol $[20,21]$, against resistant strains of $P$. aeruginosa were described (Figure 1). They possess either a 1,3-dihydroxypyridin-4-one group, a catechol bioisostere, or a catechol group, as siderophore moiety that are recognized by the OMR of this strain [17,19].

We have already reported the synthesis and the antipseudomonal activity of a series of catechol-ciprofloxacin conjugates with the monocatecholate-ciprofloxacin conjugate as the lead compound (Figure 1) [22]. Later, we have highlighted the Pvd analog aPvd3 (pFe =21.4) carrying three catechol groups as an alternative to $\mathrm{Pvd}(\mathrm{pFe}=27)$ for iron uptake by P. aeruginosa [23]. As piperazine possesses good pharmacokinetic properties, piperazine derivatives are often used for therapeutic purposes [24-26]. Especially in the antimicrobial area, this heterocycle nucleus is found in a lot of antibacterial quinolone medicine such as ciprofloxacin or antifungal drugs like posaconazole [27]. However, many recent studies reported the antimicrobial potential of $N$-substituted piperazines [26]. Additionally, particular compounds such as 1-(1-naphtylmethyl)-piperazine are known to act as efflux pump inhibitors helping to restore antibiotic activity on resistant strains [28]. Moreover, this piperazine scaffold is easily functionalizable and allows broad access to derivatives of biological interest. Thus, we decided to use the 1,4-bis(3-aminopropyl)piperazine to graft two identical iron ligands, catechol or 3-hydroxypyridin-4-one [29], to obtain a rapid access to the siderophore mimetics, $\mathbf{1}$ and $\mathbf{2}$ respectively.

Herein, we report the synthesis, the physicochemical properties and the P. aeruginosa siderophore-like activity of the piperazine-based chelators $\mathbf{1}$ and $\mathbf{2}$. 
<smiles>CC(C)(C)OC(=O)O</smiles><smiles>O=C(O)c1cn(C2CC2)c2cc(N3CCN(C(=O)c4cccc(O)c4O)CC3)c(F)cc2c1=O</smiles>

Monocatecholate-ciprofloxacin conjugate<smiles>CC(C)(O)C(=O)ON=C(C(=O)NC1C(=O)N2C(C(=O)O)=C(CN3CCCC3)CS[C@H]12)c1csc(N)n1</smiles>

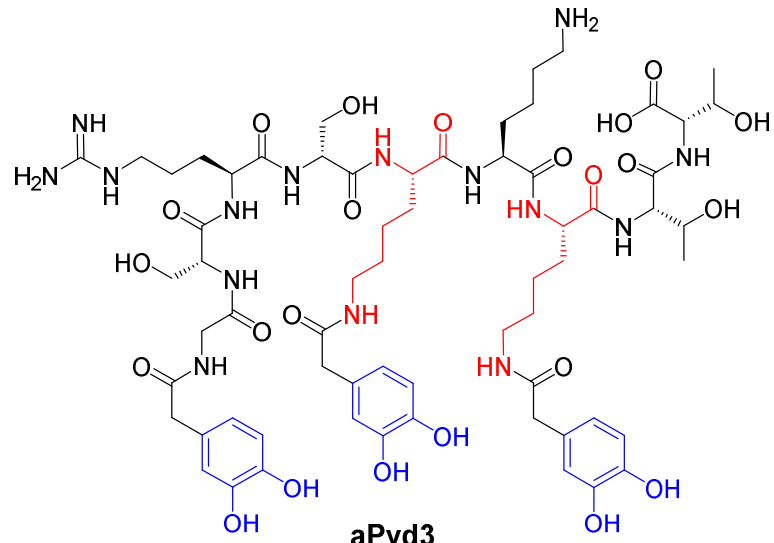<smiles>O=C(NCCCN1CCN(CCCNC(=O)c2cccc(O)c2O)CC1)c1cccc(O)c1O</smiles><smiles>Cc1c(O)c(=O)ccn1CCCN1CCN(CCCn2ccc(=O)c(O)c2C)CC1</smiles>

Figure 1. BAL-30072, cefiderocol, monocatecholate-ciprofloxacin conjugate, aPvd3 and synthesized siderophore mimetics $\mathbf{1}$ and $\mathbf{2}$.

\section{Results and Discussion}

\subsection{Siderophore Mimetics 1 and 2 Synthesis}

The synthesis of two iron chelators $\mathbf{1}$ and $\mathbf{2}$ relies on a coupling reaction between, respectively, the bidentate ligand 4 or 5 precursors and the 1,4-bis(3-aminopropyl)piperazine 3 (Figure 2).

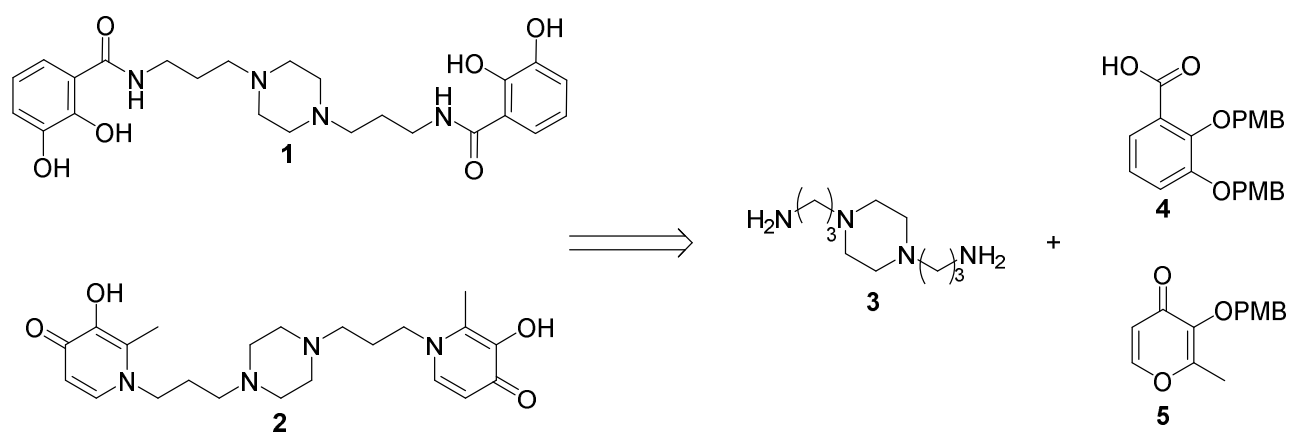

Figure 2. Retrosynthesis of the iron chelators 1 and 2.

\subsubsection{Synthesis of the Bidentate Ligand Precursors 4 and 5}

The 2,3-dihydroxybenzoic acid was protected in the presence of potassium carbonate, tetrabutylammonium iodide and $p$-methoxybenzylchloride. 6 was saponified with sodium hydroxide 
to afford the bidentate ligand 4 in two steps with a 70\% yield. The maltol was protected using potassium carbonate and $p$-methoxybenzylchloride with a $65 \%$ yield (Figure 3 ).<smiles>O=C(O)c1cccc(O)c1O</smiles><smiles>Cc1occc(=O)c1O</smiles><smiles>CCCCOc1cccc(C(=O)O[Na])c1OCCC</smiles><smiles>CCOc1cccc(C(=O)O)c1OCC</smiles>

(a)

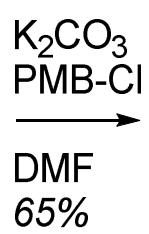<smiles>CCOc1c(C)occc1=O</smiles>

(b)

Figure 3. Synthesis of the bidentate ligands precursors (a) 4 is obtained from the 2,3-dihydroxybenzoic acid; (b) 5 is obtained from the 3-hydroxy-2-methyl-4H-pyran-4-one (maltol).

\subsubsection{Synthesis of the Iron Chelators 1 and 2}

The bidentate ligands precursors 4 and 5 were synthesized in order to be coupled with the 1,4-bis(3-aminopropyl)piperazine 3. A peptide coupling has been carried out between the precursor 4 and 3, giving 7 with a $60 \%$ yield. A condensation of the protected maltol 5 and the piperazine 3 gave 8 , with a $70 \%$ yield. The common hydrogenation step was performed using an $\mathrm{H}$-cube system generating hydrogen by electrolysis of water. 1 and $\mathbf{2}$ were, respectively, obtained in a 4 and 3-step synthesis with a $38 \%$ and $41 \%$ global yield (Figure 4 ).

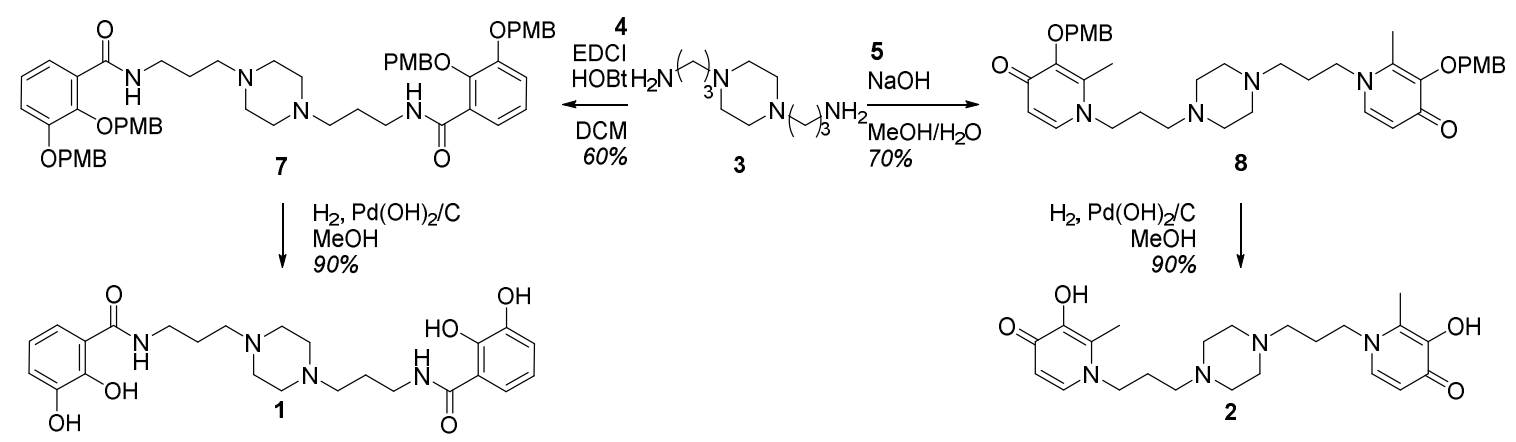

Figure 4. Synthesis of the iron chelators bearing catecholate (1) or hydroxypyridinone (2) moieties.

\subsection{Physicochemical Studies}

After synthesis, physiochemical studies have been performed on both siderophore mimetics 1 and 2.

The complexing ability towards Fe(III) of siderophores is evaluated from the pFe determination, which represents the fraction of uncomplexed $\mathrm{Fe}(\mathrm{III})$ at physiological $\mathrm{pH}(\mathrm{pH}=7.4)$, using standardized conditions ([ligand $\left.]=10^{-5} \mathrm{M},[\mathrm{Fe}]=10^{-6} \mathrm{M}, \mathrm{T}=25^{\circ} \mathrm{C}, \mathrm{I}=0.1 \mathrm{M}\right)$. The expressed $\mathrm{pFe}(\mathrm{pFe}=-\log [\mathrm{Fe}])$, represents the overall chelating ligand ability when taking into account all the complex species present in the medium and the ligand affinity. The higher the value of this parameter, the higher the chelating ability of the ligand is. The ligands we developed are often difficult to solubilize in pure water, thus restricting the study of their equilibriums with $\mathrm{Fe}(\mathrm{III})$ in solution. The simplest alternative 
then is to use mixed solvents. Thereby, complexations of Fe(III) cations with siderophore mimetics were studied in water/DMSO mixtures by potentiometry and UV-visible spectrophotometry. More specifically, the stoichiometry and the overall stability constants of all soluble species were determined. The potentiometry is based on the comparison of the neutralization curves of the ligand alone and in the presence of the metal with fluctuating ratios $R=[\mathrm{L}] /[\mathrm{M}]$, where $[\mathrm{L}]$ and $[\mathrm{M}]$ represent the analytical concentrations of the ligand and the metal introduced in solution, respectively. This method is particularly suitable to study ligands which have weak acid-base properties. Base moieties usually constitute complexation sites for the metal ions. The complexation reactions result in the release of additional protons comparatively to that of the neutralization of the ligand alone. The solution has a much more acidic character when the complexes are stable. Most often, the analysis of the titration curves allows to determine the stoichiometry of the predominant complexes. The solutions are also analyzed by mass spectrometry with electrospray ionization to facilitate and confirm the qualitative analysis of titration curves. UV-visible spectra of ligand solutions in the presence of metal are recorded, and the spectra refinement allows the determination of the formation constants of the complexes and the specific electronic spectrum of the absorbing species. Information about the geometry and the coordination modes of the metal cations can be deduced from these spectra. The agreement between the values of the formation constants determined by potentiometry, and those determined by UV-visible spectrophotometry, constitutes a validation of the proposed chemical model for each studied system. After study of the species distribution diagrams, the biologically active forms of the complexes at physiological $\mathrm{pH}$ can be identified, and the $\mathrm{pFe}$ value determined.

\subsubsection{System $\mathrm{H}+/ 1(2)$}

The ligand $\mathbf{1}$ in its fully protonated state, may release potentially six protons, two from the piperazine function and four from the two catechols. The neutralization curve was converted as a $\mathrm{z}$ versus $\mathrm{pH}$ curve taking into account that the neutral form of the ligand is $\mathrm{LH}_{4}$. The curve, performed in the absence of metal, shows an initial decrease of $\mathrm{z}$, followed by a plateau between $\mathrm{pH} 5$ and 7 for a $\mathrm{z}$ value of -0.2 (Figure 5). This is ascribed to the neutralization of the protons bound to piperazine. The negative value of $\mathrm{z}$ at the plateau indicates that the neutralization of the first hydroxyl of the catechol functions is effective in this $\mathrm{pH}$ range. The value of $z$, higher than -2 for a $\mathrm{pH}$ greater than 10 , indicates that the second hydroxyl of the catechol functions remain protonated throughout the titration.

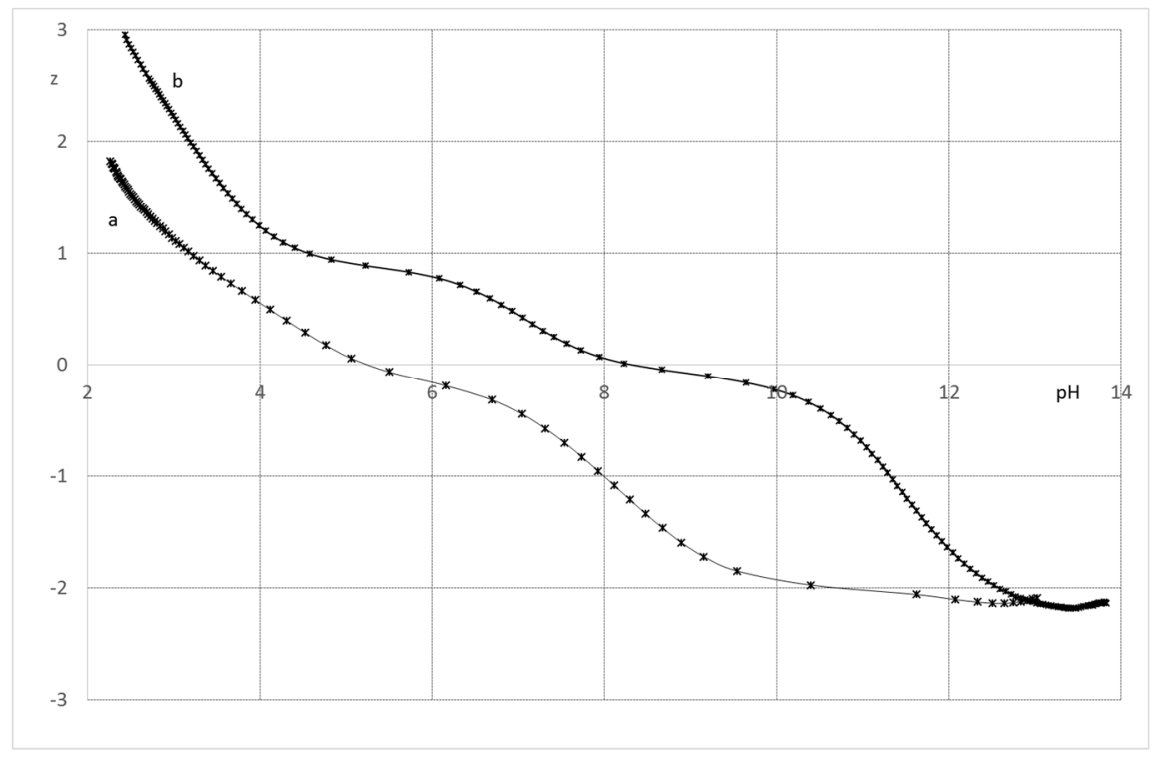

Figure 5. Average charge of the ligands as a function of $\mathrm{pH} ; \mathrm{KCl} 0.1 \mathrm{~mol} . \mathrm{L}^{-1} ; \mathrm{T}=298 \mathrm{~K}$. (a) $\mathbf{1}$; (b) 2. 
The ligand 2 has six protonable groups: two pyridinium, two piperazines and two hydroxyls. The neutral form is $\mathrm{LH}_{2}$ with the two hydroxyl groups remaining protonated. The $\mathrm{z}$ versus $\mathrm{pH}$ curve of the ligand shows three deprotonation steps. The neutralization curve of the ligand shows that at the beginning of the titration nearly $50 \%$ of the pyridine groups are protonated. The plateau between $\mathrm{pH} 4$ and 6 at a $\mathrm{z}$ value of 1 , corresponds to the neutralization of the pyridinium ions and one of the protons bound to the piperazine cycle. The second step of deprotonation, corresponding to a plateau between $\mathrm{pH} 7.5$ and 9 with a $\mathrm{z}$ value of 0 , corresponds to the loss of the second protons bound to the piperazine cycle. The decrease of $\mathrm{z}$ value above $\mathrm{pH} 8$, leading to a negative value of $\mathrm{z}$, corresponds to the neutralization of the two hydroxyl groups of the ligand (Figure 5).

Acidity constants of the $\mathbf{1}$ and $\mathbf{2}$ ligands were estimated on the basis of the global protonation constants. The protonation constant corresponds to the $\beta_{01 \mathrm{~h}}$ and is determined by refinements of neutralization curves of the ligands in the absence of metal (Table 1). The low values of the estimated standard deviation $\sigma_{\mathrm{mlh}}$ of the $\beta_{\mathrm{mlh}}$ constants, and of the global standard deviation $\sigma_{\mathrm{mlh}}$ of the $\beta_{\mathrm{mlh}}$ constants $(<0.95)$, are indicative of the validity of the models for the fitting procedure of $\mathbf{1}$ and 2 titrations.

Table 1. Protonation and acidity constants of $\mathbf{1}$ and 2.

\begin{tabular}{ccc}
\hline & $\mathbf{1}$ & $\mathbf{2}$ \\
\hline $\mathrm{pKa}_{1}$ & $2.39(4)^{1}$ & $2.21(5)$ \\
$\mathrm{pKa}_{2}$ & $3.66(4)$ & $2.82(3)$ \\
$\mathrm{pKa}_{3}$ & $6.99(6)$ & $3.72(8)$ \\
$\mathrm{pKa}_{4}$ & $8.67(8)$ & $7.17(2)$ \\
$\mathrm{pKa}_{5}$ & - & $11.09(1)$ \\
$\mathrm{pKa}_{6}$ & - & $11.79(2)$ \\
\hline
\end{tabular}

${ }^{1}$ The calculated uncertainties for $\log \beta_{\mathrm{m} 1 \mathrm{~h}}$ were determined on the basis of the standard deviation. Values in parentheses refer to estimated standard deviations for the last significant digit. $\mathrm{I}=0.1 \mathrm{~mol} . \mathrm{L}^{-1}(\mathrm{KCl}) ; \mathrm{T}=298 \mathrm{~K}$, $\mathrm{H}_{2} \mathrm{O} /$ DMSO media (v/v 50:50).

For 1 , the $\mathrm{pKa}_{1}$ and $\mathrm{pKa}_{2}$ values match well with those for the deprotonations of the nitrogen atoms of the piperazine cycle, whereas $\mathrm{pKa}_{3}$ and $\mathrm{pKa}_{4}$ correspond to the deprotonation to the first hydroxyl of the catechol function. This allocation is corroborated by the analysis of the spectrophotometric titration. Indeed, the spectra of 1 remain insensitive to $\mathrm{pH}$ variations within the $2-4.5 \mathrm{pH}$ range and show only one characteristic $\pi-\pi^{*}$ transition centered at $305 \mathrm{~nm}$. This transition is due to the absorbance of the fully protonated catechol function. Above $\mathrm{pH} 4.5$, the increase in $\mathrm{pH}$ causes a gradual shift of this transition to higher wavelengths, and the appearance of new transitions at $330 \mathrm{~nm}$, whose intensity increases with $\mathrm{pH}$. This transition is ascribed to the deprotonation of the hydroxyl groups of the catechol [30].

For 2, the $\mathrm{pKa}_{1}$ and $\mathrm{pKa}_{2}$ values match well with the value found for the deprotonations of the nitrogen atoms of the pyridinic groups, while $\mathrm{pKa}_{3}$ and $\mathrm{pKa}_{4}$ are ascribed to the deprotonation of the nitrogen atoms of the piperazine cycle [31]. The higher value of $\mathrm{pKa}_{4}$ compared to $\mathrm{pKa}_{3}$ is indicative of strong electrostatic interactions between the two nitrogen atoms of piperazine moieties. On the basis of study made on deferiprone, we can confidently attribute $\mathrm{pKa}_{5}$ and $\mathrm{pKa}_{6}$ to the neutralization of hydroxyl groups bound to the aromatic cycle [32].

\subsubsection{System $\mathrm{Fe}(\mathrm{III}) / 1(2)$}

Extensive research on siderophores and iron chelators allows the pH-based monitoring of the evolution of catechol-iron complexes by UV-vis spectrophotometry. The analysis is on the location of the ligand-to-metal charge transfer band (LMCTs) [30,33,34]. The 1:1 (Fe(III)(cat)); 1:2 (Fe(III)(cat) 2 ) and 1:3 $\left(\mathrm{Fe}(\mathrm{III})(\mathrm{cat})_{3}\right)$ species are produced at low (below $\left.\mathrm{pH} 4.5\right)$, intermediate $(\mathrm{pH} 7.5)$ and alkaline $\mathrm{pH}$ (above $\mathrm{pH}$ 9.5), respectively, and show intense specific LMCT transitions in the visible region. For 
$\mathrm{Fe}(\mathrm{III})$ (cat) complexes, LMCT bands are centered around $720 \mathrm{~nm}$, while Fe(III)(cat) $)_{2}$ and Fe(III)(cat) 3 transitions are located around 570 and $470 \mathrm{~nm}$, respectively.

The spectral characteristic of Fe(III)-1 complexes are similar to those of iron-catechol ones and indicate a progressive involvement of the catechol groups in the coordination of the metal, with the increase of $\mathrm{pH}$ (Figure 6). Indeed, beyond $\mathrm{pH} 4$, and the LMCT for the Fe(III)-1 solution is close to $700 \mathrm{~nm}$, and is easily related to the formation of a complex with one catechol group bound to the metal. Mass spectrum of $\mathrm{Fe}(\mathrm{III})-\mathbf{1}$ indicate the formation of a 1:1 complex detected in positive mode at $m / z=526.15$ corresponding to $[\mathrm{Fe}+\mathrm{L}-2 \mathrm{H}]^{+}$. The isosbestic point between $\mathrm{pH} 5$ and 8 corresponds to an equilibrium between the 1:1 and 2:2 complexes. The 2:2 complex shows a transition centered at $580 \mathrm{~nm}$, corresponding to the coordination of two catechols from distinct ligands, on two Fe(III) centers. The transitions shift between $\mathrm{pH} 7.5$ and 9 towards higher energy is ascribed to the formation of the 2:3 species by addition of a third ligand on the metal centers. This complex shows a transition at $500 \mathrm{~nm}$, characteristic of a Fe(cat) ${ }_{3}$ chromophore $[30,33,34]$. The $2: 3$ species was detected at high $\mathrm{pH}$ by mass spectrometry in negative mode as a discharged species at $m / z=882[2 \mathrm{Fe}+3 \mathrm{~L}+4 \mathrm{Na}+2 \mathrm{DMSO}-6 \mathrm{H}]$.

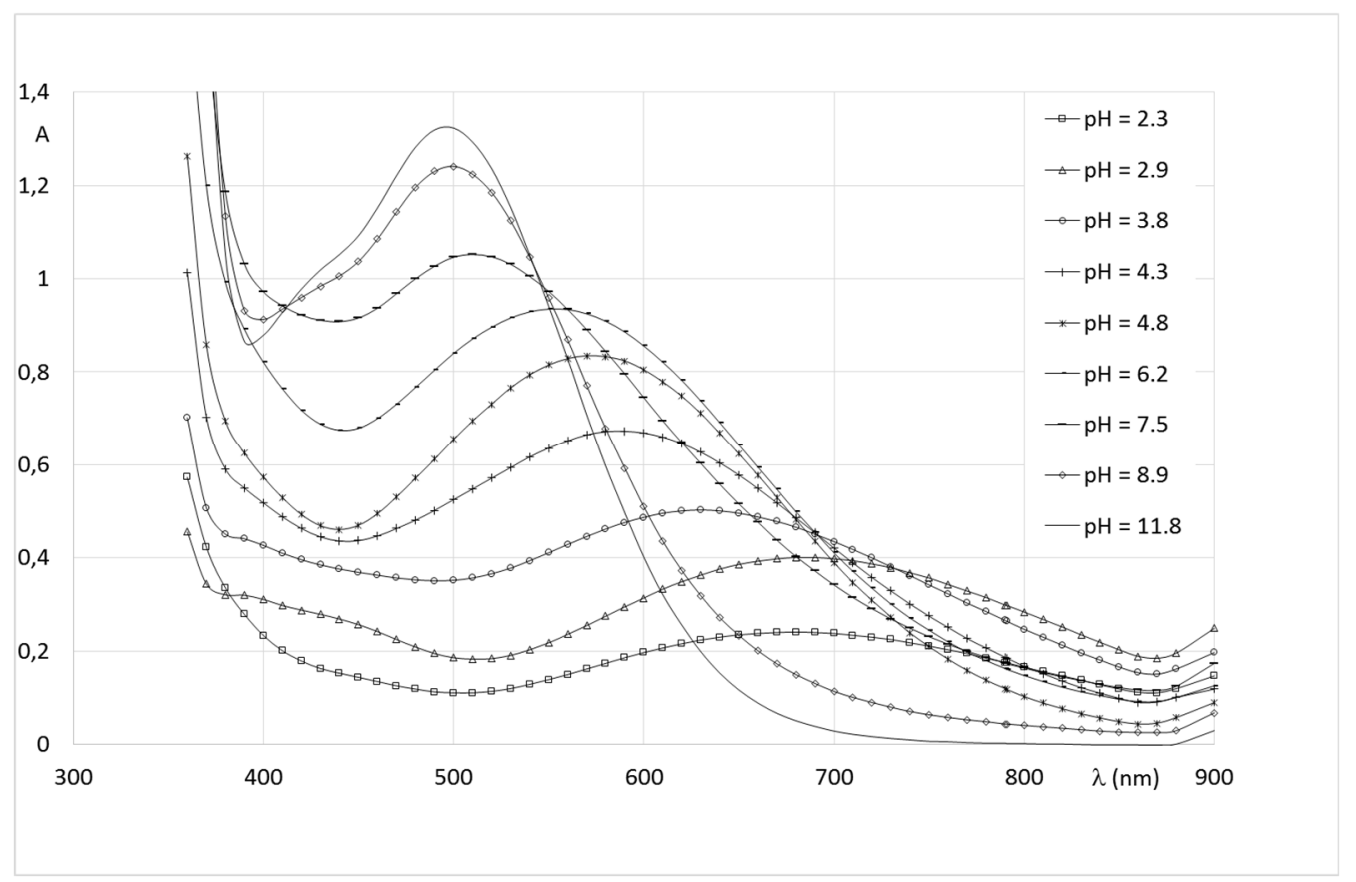

Figure 6. Spectrophotometric titration of Fe(III)-1 solutions.

The spectral evolution of $\mathrm{Fe}(\mathrm{III}) / \mathbf{2}$ solutions with $\mathrm{pH}$, (Figure 7) present similar features to those as reported by Nurchi et al. on the system Fe(III)-deferiprone [32]. The absorbance properties of solutions show that the coordination of oxygen atoms of the aromatic groups is effective from the beginning of titration. From $\mathrm{pH} 2$ to 2.7, the spectra show an intense transition at $510 \mathrm{~nm}$, growing with $\mathrm{pH}$, corresponding to a molar absorbance greater than $3000 \mathrm{~mol}^{-1} \cdot \mathrm{dm}^{+3} . \mathrm{cm}^{-1}$. On the basis of the results, this transition ascribed to an LMCT transition, generated by the coordination of two ligands, to form a chromophore $\mathrm{Fe}\left(\mathrm{O}_{\mathrm{ar}}\right)_{4}\left(\mathrm{O}_{\mathrm{w}}\right)_{2}$ around the metal center. Mass spectra recorded in the $\mathrm{pH}$ range indicate that it corresponds to a complex of stoichiometry 2:2. Indeed, in this $\mathrm{pH}$ range, only one complex species is detected in positive mode at $m / z=470.1$. The simulation of the isotopic cluster shows the unique formation of a $2 / 2$ discharged complex in this $\mathrm{pH}$ range corresponding to $\mathrm{Fe}_{2} \mathrm{~L}_{2} \mathrm{H}_{-4}[2 \mathrm{Fe}+2 \mathrm{~L}$ $\left.-4 \mathrm{H}^{+}\right]^{2+}$. The spectrophotometric titration shows an isosbestic point between $\mathrm{pH} 2.7$ and 4.2 that reflects equilibria between two chromophores. However, the mass spectra of solutions in this $\mathrm{pH}$ range do not show additional species, which seems to indicate that the isosbestic points correspond to an equilibrium between two deprotonated forms of a 2:2 species, unlike the results of Nurchi et al. which propose the coordination of a third molecule of deferiprone around the metal center. The mass 
spectrum recorded at $\mathrm{pH} 9$ shows two additional peaks with very low intensity at $\mathrm{m} / \mathrm{z}=1355$ and 1377 , corresponding to an adduct of a $2: 3$ species $[2 \mathrm{Fe}+3 \mathrm{~L}-5 \mathrm{H}]^{+}$and $[2 \mathrm{Fe}+3 \mathrm{~L}-6 \mathrm{H}+\mathrm{Na}]^{+}$formed to a small extent.

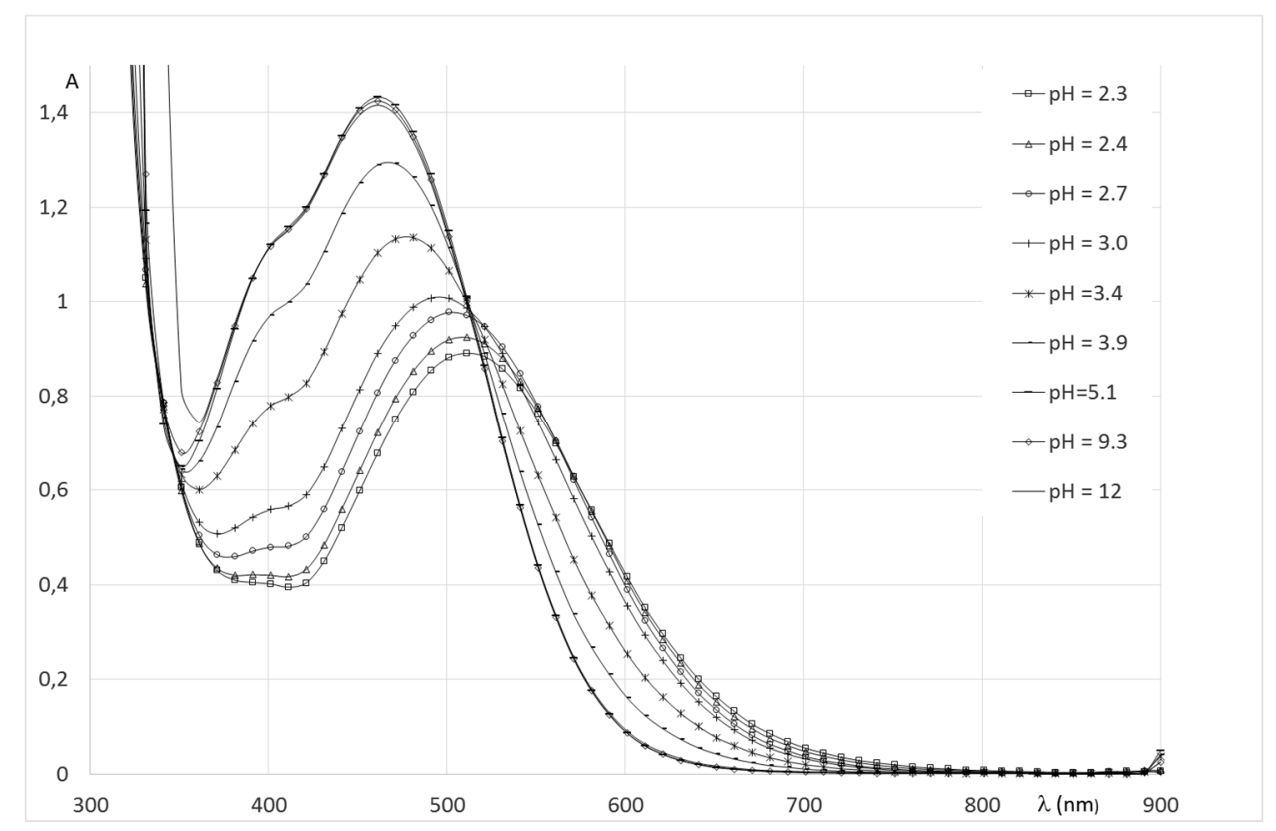

Figure 7. Spectrophotometric titration of Fe(III)-2 solutions.

Refinements of potentiometric titrations allow the determination of stability constants $\left(\beta_{\mathrm{mlh}}\right)$ for the Fe(III)-1 and Fe(III)-2 complexes. To this purpose, the features of spectrophotometric titrations, and the results of mass spectrometry were highly considered to define the best chemical model for both systems (Table 2).

Table 2. Global formation constant of Fe(III)-1 and Fe(III)-2 complexes.

\begin{tabular}{cccc}
\hline & & $\log \boldsymbol{\beta} \mathbf{1}$ & $\log \boldsymbol{\beta} \mathbf{2}$ \\
\hline $\mathrm{Fe}(\mathrm{LH})$ & $\log \beta_{111}$ & $18.17(6)^{1}$ & - \\
$\mathrm{Fe}_{2}(\mathrm{LH})_{2}$ & $\log \beta_{222}$ & & $67.25(3)$ \\
$\mathrm{Fe}_{2} \mathrm{~L}_{2}$ & $\log \beta_{220}$ & $31.87(6)$ & $61.73(4)$ \\
$\mathrm{Fe}_{2} \mathrm{~L}\left(\mathrm{LH}_{-1}\right)$ or $\mathrm{Fe}_{2} \mathrm{~L}_{2}(\mathrm{OH})$ & $\log \beta_{22-1}$ & $27.0(5)$ & $58.58(4)$ \\
$\mathrm{Fe}_{2}\left(\mathrm{LH}_{-1}\right)_{2}$ or $\mathrm{Fe}_{2} \mathrm{~L}_{2}(\mathrm{OH})_{2}$ & $\log \beta_{22-2}$ & $23.4(1)$ & $54.68(5)$ \\
$\mathrm{Fe}_{2}\left(\mathrm{LH}_{-2}\right)\left(\mathrm{LH}_{-1}\right)$ or $\mathrm{Fe}_{2} \mathrm{~L}_{2}(\mathrm{OH})_{3}$ & $\log \beta_{22-3}$ & $18.8(1)$ & $47.45(6)$ \\
$\mathrm{Fe}_{2} \mathrm{~L}_{3}$ & $\log \beta_{230}$ & & $79.43(1)$ \\
$\mathrm{Fe}_{2}\left(\mathrm{LH}_{-1}\right)_{3}$ & $\log \beta_{23-3}$ & $27.92(3)$ & \\
$\mathrm{Fe}_{2}\left(\mathrm{LH}_{-1}\right)_{2}\left(\mathrm{LH}_{-2}\right)$ & $\log \beta_{23-4}$ & $18.8(5)$ & \\
$\mathrm{Fe}_{2}\left(\mathrm{LH}_{-1}\right)\left(\mathrm{LH}_{-2}\right)_{2}$ & $\log \beta_{23-5}$ & $10.2(6)$ & \\
$\mathrm{Fe}_{2}\left(\mathrm{LH}_{-2}\right)_{3}$ & $\log \beta_{23-6}$ & $0.6(1)$ & \\
\hline
\end{tabular}

${ }^{1}$ Values in parentheses refer to estimated standard deviations. 
In order to make these equilibrium constants more explicit, the distribution curves of the various species were plotted as a function of $\mathrm{pH}$ for $\mathrm{R}=5$ (Figure 8).

For the Fe(III)-1 system, the speciation curve underlines the formation of complexes above $\mathrm{pH} 2$. The distribution curves agree with the spectrophotometric titration and underline a maximum for the formation of $\mathrm{Fe}(\mathbf{1})$ complexes at $\mathrm{pH} 3.2$ (corresponding to the maximum of the formation of the species $\left.\mathrm{Fe}(\mathrm{LH})^{+}\right)$, and the maximum for the formation of $\mathrm{Fe}_{2}(\mathbf{1})_{2}$ is located at $\mathrm{pH} 4.6$ and corresponds to an equilibria between $\mathrm{Fe}_{2} \mathrm{~L}_{2} \mathrm{H}_{-2}$ and $\mathrm{Fe}_{2} \mathrm{~L}_{2} \mathrm{H}_{-3}$, whereas $\mathrm{Fe}_{2}(\mathbf{1})_{3}$ complexes predominate above $\mathrm{pH}$ 5. In all cases, for 1:1 and 2:2 complexes, the successive deprotonation steps correspond to the loss of the protons of the second hydroxyl groups of the catechol function.

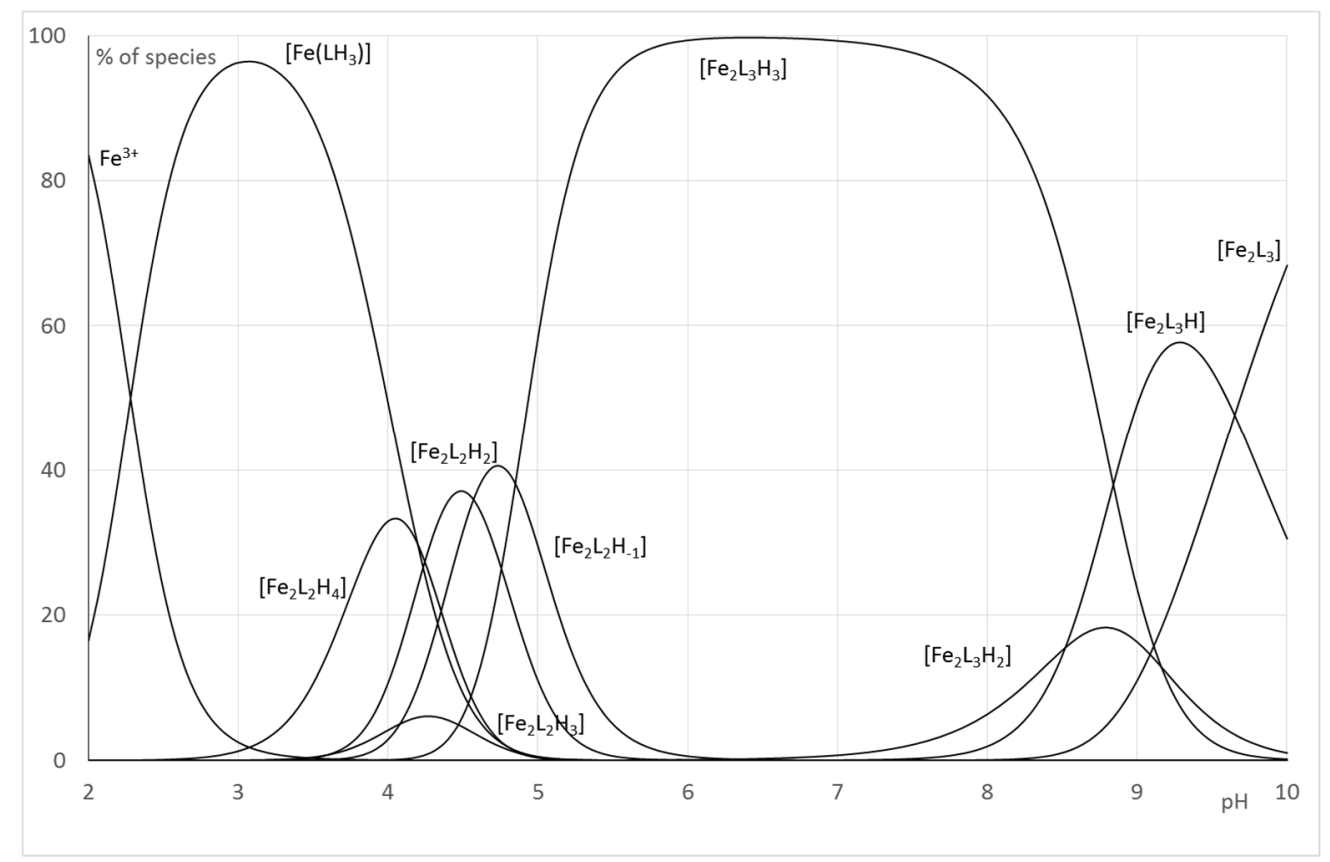

Figure 8. Distribution curves for the Fe-1 systems $\left(\mathrm{CL}=1 \cdot 10^{-3} \mathrm{~mol} \cdot \mathrm{L}^{-1} ; \mathrm{Cm}=2 \cdot 10^{-4} \mathrm{~mol} \cdot \mathrm{L}^{-1}\right)$.

For the Fe(III)-2, the best refinements, in accordance with the interpretation of spectrophotometric titrations and mass spectra recorded at variable $\mathrm{pH}$, confirm the formation of 2:2 species on the whole $\mathrm{pH}$ range. The change of chromophore beyond $\mathrm{pH} 3$ corresponds to the deprotonation to the neutralization of nitrogen atoms of pyridine groups and aromatic hydroxyl groups to form $\mathrm{Fe}_{2} \mathrm{~L}_{2}$. Above $\mathrm{pH} 3$, the further deprotonations species do not induce modification of the absorbance properties of $\mathrm{Fe}(\mathrm{III})-2$ solutions. It is reasonable to consider that it concerns a loss of protons from coordinated water molecules. Consequently, the formation constant $\beta_{22-1,} \beta_{22-2}$ and $\beta_{22-3}$ correspond mainly to stoichiometry $\mathrm{Fe}_{2} \mathrm{~L}_{2}(\mathrm{OH})_{\mathrm{n}}$. The $\mathrm{Fe}_{2} \mathrm{~L}_{3}$ which has been detected in small extent by mass spectrometry was included in our refinements (Figure 9). 


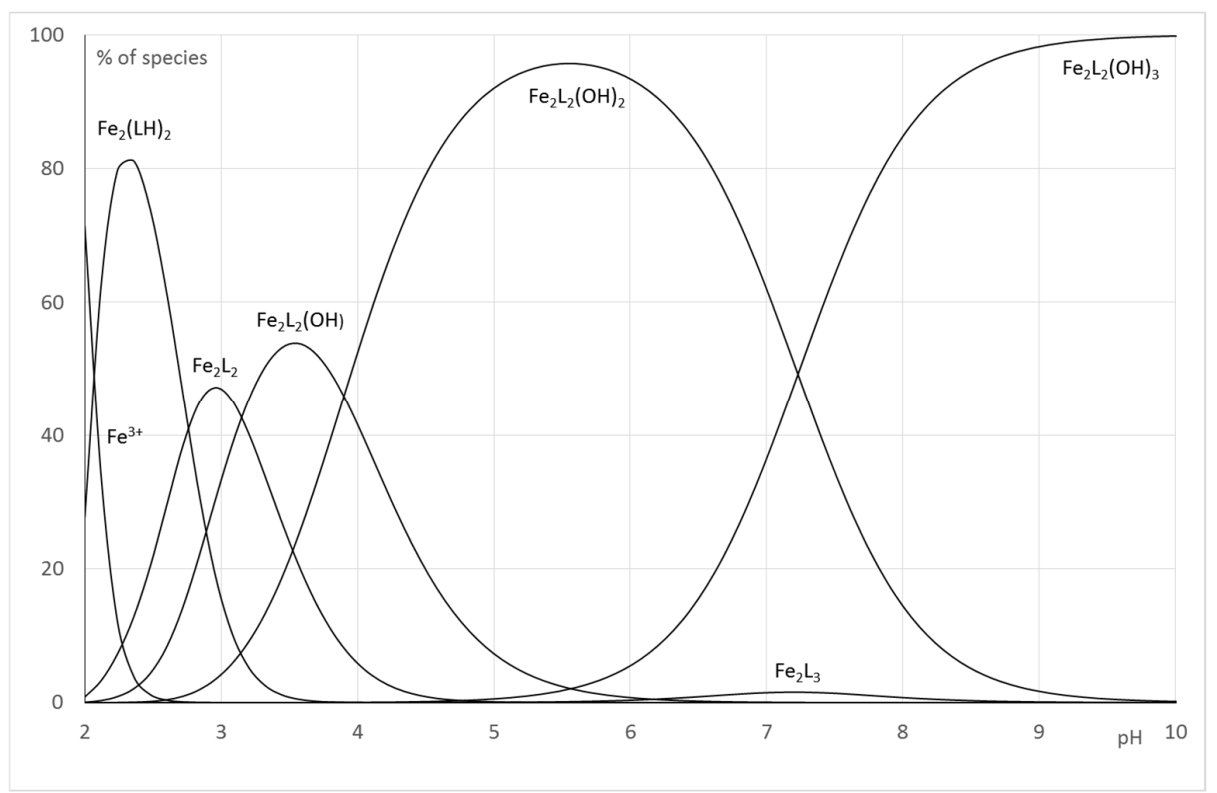

Figure 9. Distribution curves for the Fe-2 systems $\left(C L=1.10^{-3} \mathrm{~mol} \cdot \mathrm{L}^{-1} ; \mathrm{Cm}=2.10^{-4} \mathrm{~mol} \cdot \mathrm{L}^{-1}\right)$.

In designing iron chelators for clinical applications, metal selectivity and ligand-metal complex stability are of paramount importance. The most suitable way to compare the Fe(III) chelating ability between ligands $\mathbf{1}$ and $\mathbf{2}$, is to determine $\mathrm{pFe}$. Unlike stability constants, $\mathrm{pFe}$ takes into account the effects of ligand basicity, ligand protonation, and metal hydrolysis as well as differences in metal-ligand stoichiometry. The $\mathrm{pFe}$ was derived from ligand protonation and Fe-complex formation constants. For clinically relevant conditions, $\mathrm{pFe}$ values are typically calculated in pure water at $\mathrm{pH} 7.45$ for total ligand and Fe concentrations equal to $10^{-5}$ and $10^{-6}$ mol. $\mathrm{L}^{-1}$, respectively. Here, taking into account the extended $\mathrm{pH}$ range due to DMSO, the free $\mathrm{Fe}(\mathrm{III})$ concentration was calculated at $\mathrm{pH} 8.44$ (see the Experimental Section). The value of pFe obtained for Fe(III)-2 and Fe(III)-1 are, respectively, 24.38 and 28.04. Compared to the strongest iron chelator, enterobactin ( $\mathrm{pFe}=35.5), \mathbf{1}$ and $\mathbf{2}$ possess inferior $\mathrm{Fe}(\mathrm{III})$ complexing abilities. In both cases, the values of $\mathrm{pFe}(>20)$ meet the criteria as an iron chelation therapy agent. Nonetheless, only 1 shows a pFe superior to $\mathrm{Pvd}(\mathrm{pFe}=27)$, the endogenous siderophore of P. aeruginosa [35-37], as shown in Figure 10.
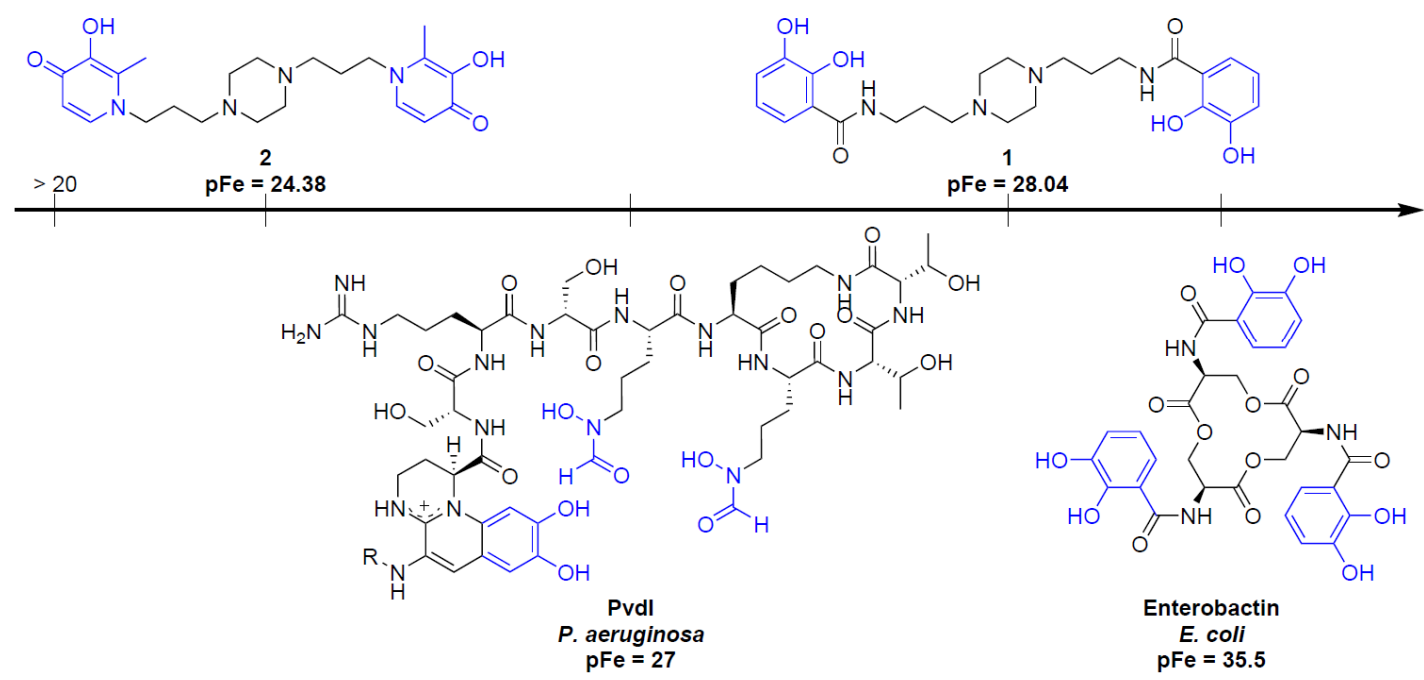

Figure 10. Comparison of $\mathrm{pFe}$ values of 1, 2, PvdI and enterobactin. 


\subsection{Antibacterial Activities}

The antibacterial activity of the siderophore mimetics $\mathbf{1}$ and $\mathbf{2}$ was measured on P. aeruginosa DSM 1117 in both cation-supplemented Mueller-Hinton (MH) Broth, as advised by the Clinical and Laboratory Standards Institute (CLSI) [38], and in Succinate Minimum Medium (SMM), a medium virtually deprived of iron. The Minimum Inhibitory Concentration (MIC) was measured with a concentration range of 0.25 to $512 \mathrm{mg} \cdot \mathrm{L}^{-1}$ and was determined as the lowest concentration at which wells remain clear. Ciprofloxacin was used as the control and displayed MICs values of $0.5 \mathrm{mg} \cdot \mathrm{L}^{-1}$. No intrinsic antibacterial activity was observed for $\mathbf{1}$ and $\mathbf{2}$ since the MICs measured are greater than $512 \mathrm{mg} \cdot \mathrm{L}^{-1}$ for both. The cytotoxicity was also evaluated on the Hep-G2 cell line, a human liver cancer cell line. 1 and $\mathbf{2}$ did not show toxicity at concentrations greater than $100 \mathrm{mmol} \cdot \mathrm{L}^{-1}$ (Table 3 ).

Table 3. Antipseudomonal activities and cytotoxicity of $\mathbf{1}$ and $\mathbf{2}$.

\begin{tabular}{ccc}
\hline & Activity & Cytotoxicity \\
\hline Compound & MIC $^{\mathbf{1}}\left(\mathbf{m g} \cdot \mathbf{L}^{-\mathbf{1}}\right)$ & IC $_{\mathbf{5 0}}{ }^{\mathbf{2}} \mathbf{( \mathbf { m m o l } \cdot \mathbf { L } ^ { - \mathbf { 1 } } )}$ \\
\hline \multirow{2}{*}{$\mathbf{1}$} & $>512(\mathrm{MH})^{3}$ & $>100$ \\
& $>512(\mathrm{SMM})^{4}$ & $>100$ \\
\multirow{2}{*}{$\mathbf{2}$} & $>512(\mathrm{MH})$ & \\
& $>512(\mathrm{SMM})$ & - \\
\hline \multirow{2}{*}{ Ciprofloxacin } & $0.5(\mathrm{MH})$ & \\
& $0.5(\mathrm{SMM})$ &
\end{tabular}

${ }^{1}$ MIC: Minimum Inhibitory Concentration on P. aeruginosa DSM 1117 strains; ${ }^{2} \mathrm{IC}_{50}$ : half maximal Inhibitory Concentration on Hep-G2 cell line; ${ }^{3}$ MH: Mueller-Hinton Medium; ${ }^{4}$ SMM: Succinate Minimum Medium.

\subsection{Siderophore-Like Activities}

A first screening of the siderophore mimetics has been carried out using growth experiments with P. aeruginosa PAO1 as a reference strain, (Deutsche Sammlung für Mikroorganismen, Braunschweig, Germany), and its pyoverdine and pyochelin-double deficient mutant P. aeruginosa PAD07 [39]. SMM was used to evaluate the siderophore-like activity of $\mathbf{1}$ and $\mathbf{2}$ without and with the addition of a known amount of ferric iron. Controls, without the tested compounds, show the natural bacterial growth under these latter conditions. The microbial development was followed by measuring the optical density at $600 \mathrm{~nm}\left(\mathrm{OD}_{600 \mathrm{~nm}}\right)$ [40]. Figure $11 \mathrm{a}$,c and Figure 12a,c represent the Pseudomonas straiN's growth in function of the siderophore mimetics concentration ([L]), and Figure 11b,d and Figure 12b,d show their growth in function of the ratio [L]/[Fe(III)]. For 1, as demonstrated by physicochemical studies, the predominant complex at physical $\mathrm{pH}$ is $\mathrm{Fe}_{2} \mathrm{~L}_{3}$. Thus, we worked assuming that above a 1.5 ratio, all the free $\mathrm{Fe}(\mathrm{III})$ was chelated. At $\mathrm{pH}$ 7, two species coexist for 2, $\mathrm{Fe}_{2} \mathrm{~L}_{2}(\mathrm{OH})_{2}$ and $\mathrm{Fe}_{2} \mathrm{~L}_{2}(\mathrm{OH})_{3}$, corresponding to a ratio equal to 1 .

As shown in Figure 11a, without supplementation of iron, the addition of $1(2.1-270 \mu \mathrm{M})$ only slightly changed the growth of $P$. aeruginosa PAD07. With iron, the growth of this strain with 1 (1/Fe(III):0.03125 to $\left.4,0.32<\mathrm{OD}_{600 \mathrm{~nm}}<0.42\right)$ is superior to the control $\left(67 \mu \mathrm{M}\right.$ of $\mathrm{FeCl}_{3}, \mathrm{OD}_{600 \mathrm{~nm}}=0.31$, Figure 11b). In Figure 11c, the increasing addition of $2(2.03-260 \mu \mathrm{M})$, without supplementation of iron, limits the growth of P. aeruginosa PAD07. As observed for 1, with iron, the addition of 2 (2/Fe(III):0.03125 to $\left.4,0.35<\mathrm{OD}_{600 \mathrm{~nm}}<0.44\right)$ allows a higher growth than the control $\left(65 \mu \mathrm{M}\right.$ of $\mathrm{FeCl}_{3}$, $\mathrm{OD}_{600 \mathrm{~nm}}=0.35$, Figure 11d). The growth stimulating activity of the two iron chelators are quite comparable. The increasing addition of $1(2.1-270 \mu \mathrm{M})$ or $2(2.03-260 \mu \mathrm{M})$, without supplementation of iron, results in dose-dependent growth of P. aeruginosa PAO1 (Figure 12a,c). This bacterial growth could be explained by a Pvd production. Indeed, we have observed a dose dependent yellow-green coloration, characteristic of the uncomplexed Pvd. In iron supplemented SMM, the bacterial growth of P. aeruginosa PAO1 is facilitated by the addition of $\mathbf{1}$ (1/Fe(III):0.03125 to 4$)$ or $\mathbf{2}$ (2/ $/ \mathrm{Fe}(\mathrm{III}): 0.03125$ to 4$)$ (Figure 12b,d). In both cases, the bacterial growth is greater than those of the control $(65$ or $67 \mu \mathrm{M}$ of 
$\left.\mathrm{FeCl}_{3}, \mathrm{OD}_{600 \mathrm{~nm}}=0.33\right)$. This growth is slightly higher for $1\left(0.38<\mathrm{OD}_{600 \mathrm{~nm}}<0.52\right)$ compared to 2 $\left(0.35<\mathrm{OD}_{600 \mathrm{~nm}}<0.45\right)$. Moreover, the growth of $P$. aeruginosa PAO1 is slightly greater than those of $P$. aeruginosa PAD07 with the addition of $\mathbf{1}$ (Figure 11b vs. Figure 12b) or $\mathbf{2}$ (Figure 11d vs. Figure 12d).

These different results suggest that $\mathbf{1}$ and $\mathbf{2}$ could be internalized by the bacteria. The difference of bacterial growth for P. aeruginosa PAO1 compared to P. aeruginosa PAD07, in iron supplemented SMM, with the addition of $\mathbf{1}$ or $\mathbf{2}$, could be due to a Pvd's additional effect in iron transport. The greater growth effect of 1 compared to 2 could be partly explained in terms of an iron chelator property: the pFe value of $\mathbf{1}$ (28.04) is close to Pvd's (27), while the pFe value of 2 (24.38) is lower than those of Pvd's (27).

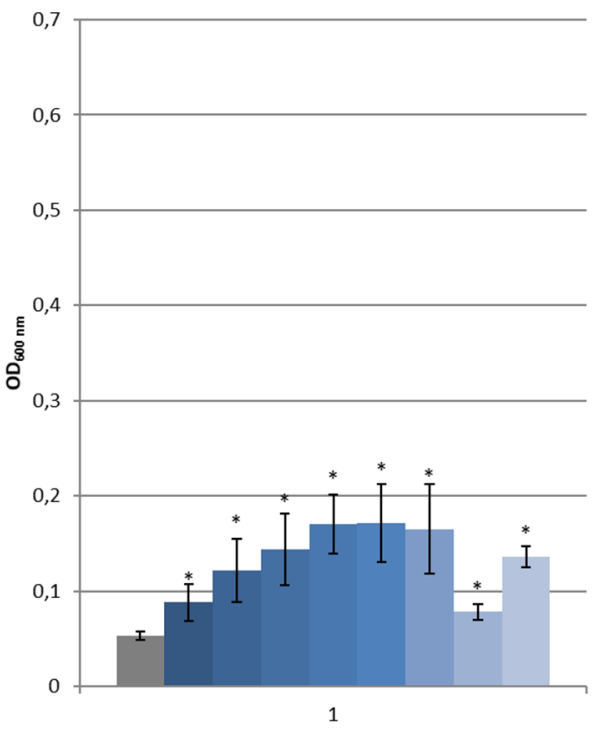

(a)

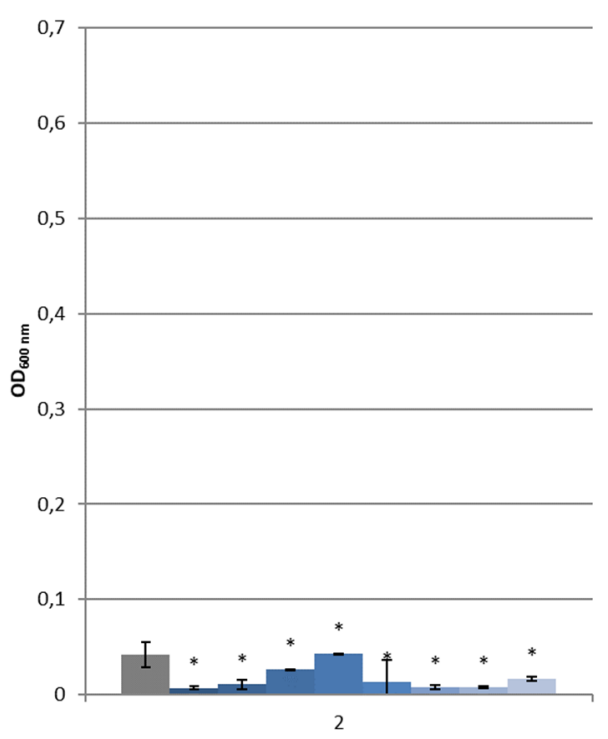

(c)

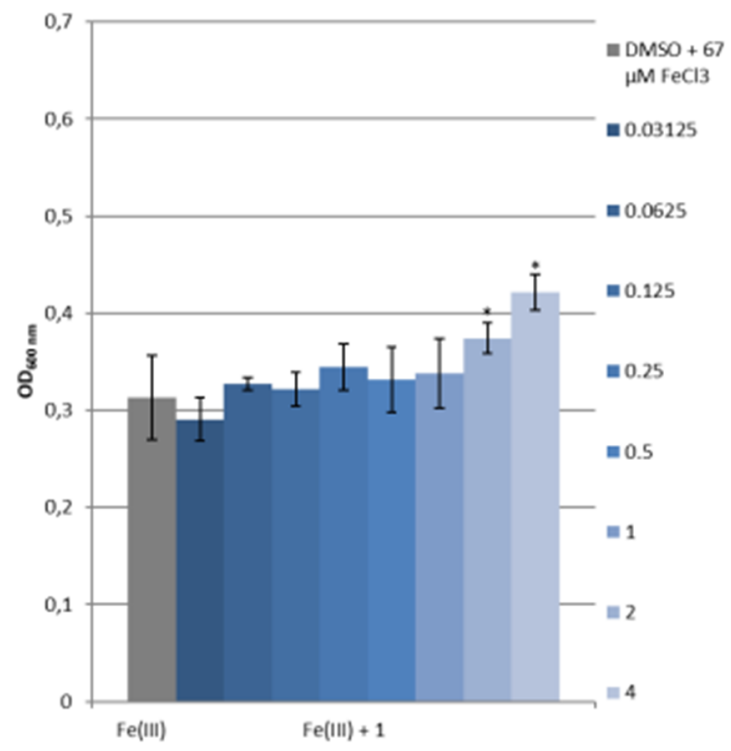

(b)

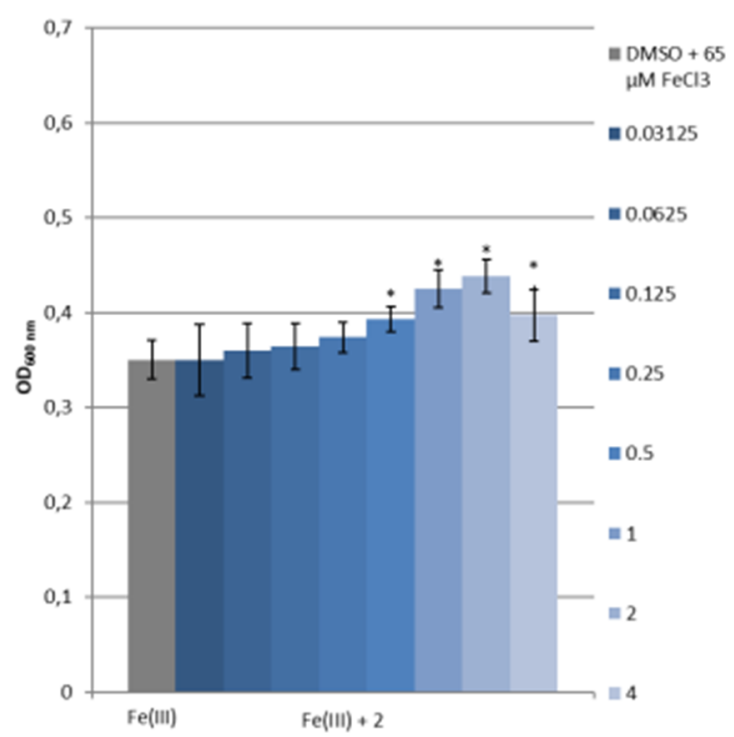

(d)

Figure 11. Growth of P. aeruginosa PAD07 in SMM (a) without ferric iron and with 1, (b) with ferric iron and with 1, (c) without ferric iron and with 2 or (d) with ferric iron and with $\mathbf{2}$. Values given in the caption at the right of the histograms indicate for $(\mathbf{a}, \mathbf{c})$ the $[\mathbf{L}]$ concentration in $\mu \mathrm{M}$ and for $(\mathbf{b}, \mathbf{d})$ the $[\mathrm{L}] /[\mathrm{Fe}(\mathrm{III})]$ molecular ratios. *: $p<0.05$ (vs. control, Mann-Whitney test). 


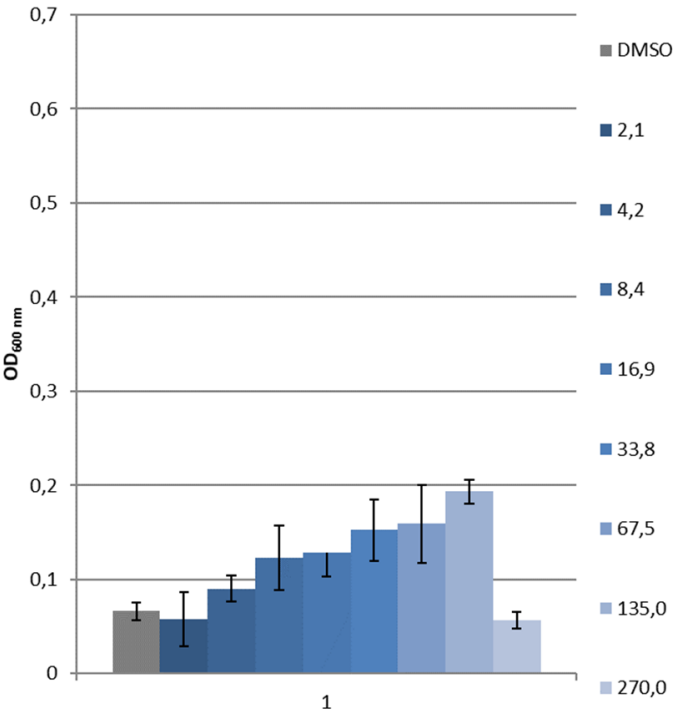

(a)

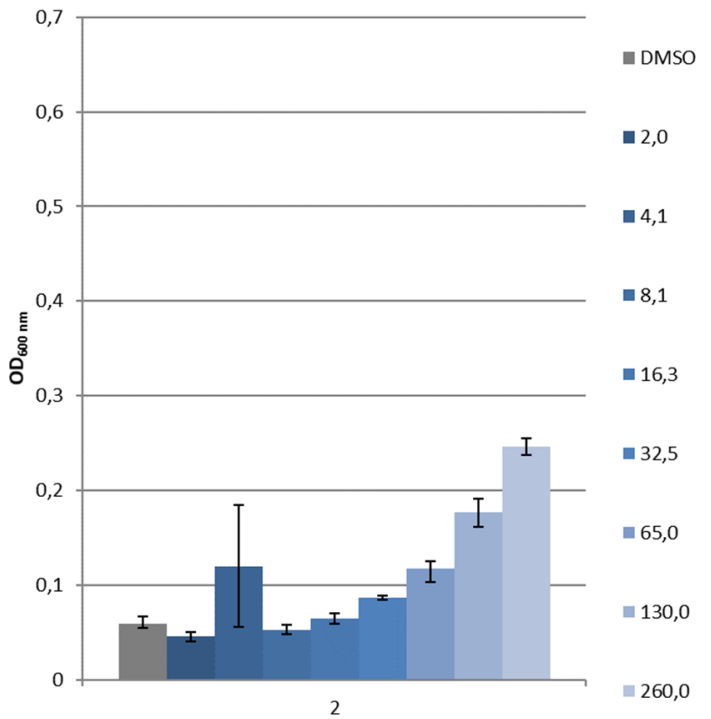

(c)

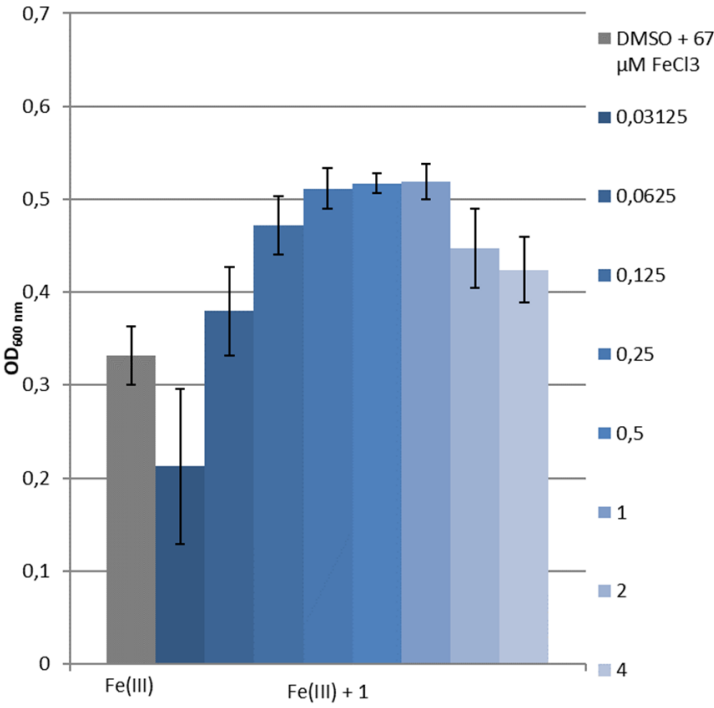

(b)

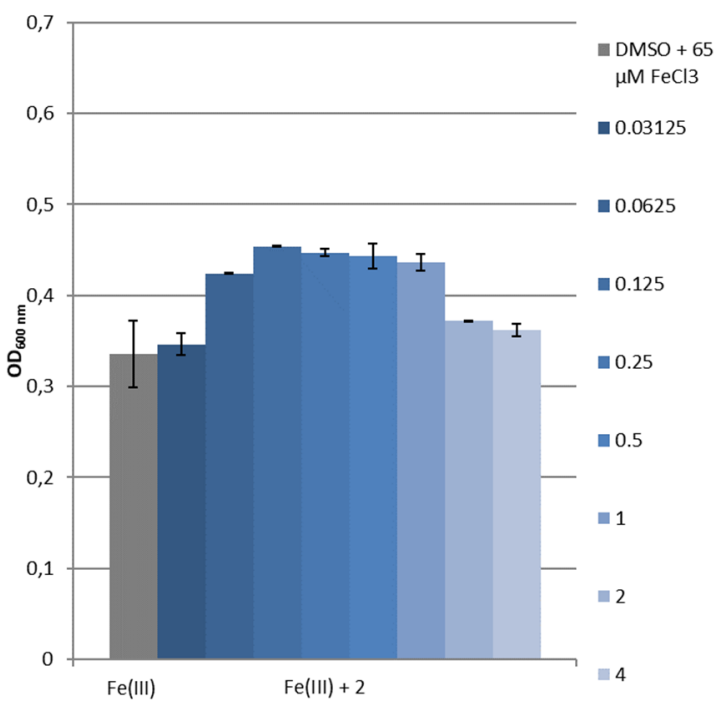

(d)

Figure 12. Growth of P. aeruginosa PAO1 in SMM (a) without ferric iron and with $\mathbf{1}$, (b) with ferric iron and with 1, (c) without ferric iron and with 2 or (d) with ferric iron and with $\mathbf{2}$. Values given in the caption at the right of the histograms indicate for $(\mathbf{a}, \mathbf{c})$ the $[\mathbf{L}]$ concentration in $\mu \mathrm{M}$ and for $(\mathbf{b}, \mathbf{d})$ the $[\mathrm{L}] /[\mathrm{Fe}(\mathrm{III})]$ molecular ratios.

According to these data, we used these iron piperazine-based chelators $\mathbf{1}$ and $\mathbf{2}$ to internalize, within P. aeruginosa, toxic metal such as gallium. Consequently, Ga(III)-1 and $\mathbf{2}$ complexes were synthetized (see Supplementary Data), and their antibacterial activities were measured on P. aeruginosa DSM 1117 in both MH and SMM, such as previously described in 2.3 (Table 4). Unfortunately, no intrinsic antibacterial activity was observed for $\mathrm{Ga}(\mathrm{III})-\mathbf{1}$ and $\mathbf{2}$ complexes since the MICs measured are greater than $512 \mathrm{mg} . \mathrm{L}^{-1}$ for both. The cytotoxicity was also evaluated on the Hep-G2 cell line, a human liver cancer cell line. Ga(III)-1 and $\mathbf{2}$ complexes did not show toxicity at concentrations greater than 100 mmol. $\mathrm{L}^{-1}$. 
Table 4. Antipseudomonal activities and cytotoxicity of Ga(III)-1 and Ga(III)-2.

\begin{tabular}{ccc}
\hline & Activity & Cytotoxicity \\
\hline Compound & MIC $^{\mathbf{1}}\left(\mathbf{m g}^{-L^{-1}}\right)$ & IC $\left._{\mathbf{5 0}}{ }^{\mathbf{2}} \mathbf{( m m o l . L}^{-\mathbf{1}}\right)$ \\
\hline Ga(III)-1 & $\begin{array}{c}>512(\mathrm{MH})^{3} \\
>512(\mathrm{SMM})^{4}\end{array}$ & $>100$ \\
\hline Ga(III)-2 & $>512(\mathrm{MH})$ & $>100$ \\
\hline
\end{tabular}

${ }^{1}$ MIC: Minimum Inhibitory Concentration on P. aeruginosa DSM 1117 strains; ${ }^{2} \mathrm{IC}_{50}$ : half maximal Inhibitory Concentration on Hep-G2 cell line; ${ }^{3}$ MH: Mueller-Hinton Medium; ${ }^{4}$ SMM: Succinate Minimum Medium.

\section{Materials and Methods}

\subsection{Synthesis}

All commercially available products were used without further purification unless otherwise specified. All solvents were dried via literature procedures when reactions required anhydrous conditions, or used without further purification. Flash column chromatography purifications were carried out on silica gel (Kieselgel 60, 40-63 $\mu \mathrm{m}, 230-400$ mesh ASTM, Merck, Darmstadt, Germany). Analytical TLC were performed on precoated silica gel 60 F254 plates (Merck) and the compounds were visualized under a UV light $(254 \mathrm{~nm})$, and with ethanolic phosphomolybdic acid. Hydrogenation was performed using the hydrogen generation system of the H-Cube ${ }^{\circledR}$ Mini (ThalesNano, Budapest, Hungary). Melting points (mp) were determined on a Stuart SMP3 apparatus and reported uncorrected. Infrared spectra were recorded on a Jasco FT/IR-4200 spectrometer system coupled to an ATR module. The wavelengths $\sqrt{ }$ obtained are expressed in $\mathrm{cm}^{-1}$. ${ }^{1} \mathrm{H}$ and ${ }^{13} \mathrm{C}$ NMR spectra were recorded using Bruker $400 \mathrm{MHz}$ spectrometer. Chemical shifts are reported in parts per million $(\delta, \mathrm{ppm})$ and the signals are quoted as s (singlet), bs (broad singlet), $\mathrm{d}$ (doublet), bd (broad doublet), dd (doublet of doublet), $\mathrm{dt}$ (doublet of triplet), $\mathrm{t}$ (triplet), bt (broad triplet), q (quartet), bq (broad quartet), and m (multiplet). J values are given in Hertz. Signals assignments were made using HMBC, HSQC, COSY, and NOESY experiments when necessary. LC-HRMS analyses were performed on an ACQUITY UPLC H-Class system (Waters-Micromass, Manchester, UK) coupled with a SYNAPT G2-Si Q-TOF hybrid quadrupole time-of-flight instrument (Waters-Micromass, Manchester, UK), equipped with an electrospray (ESI) ionization source (Z-spray), and an additional sprayer for the reference compound (Lock Spray, Torrance, CA, USA) heated at $50{ }^{\circ} \mathrm{C}$. For liquid chromatography coupled with mass spectrometry (LCMS), UV chromatograms and mass spectra were obtained from a Shimadzu LCMS-2020 system, at $190 \mathrm{~nm}$, and by positive ESI-MS interface (detection mode: scan, interface voltage: tuning file, DL voltage: $100 \mathrm{~V}$, Q-array DC: $40 \mathrm{~V}$, Q-array RF: 40 V). The gradient elution was performed on a Phenomenex Kinetex ${ }^{\circledR}$ HPLC C18 column using an injection volume of $1-2 \mu \mathrm{L}$, and a mobile phase composed of water/acetonitrile (solvent A/solvent B) with $0.1 \%$ formic acid (98:2 during 2 min, 55:45 during $2 \mathrm{~min}$, and $45: 55$ during $3 \mathrm{~min}$ with a flow of $0.3 \mathrm{~mL} / \mathrm{min}$ at $40^{\circ} \mathrm{C}$ ).

\section{4-methoxybenzyl 2,3-bis((4-methoxybenzyl)oxy)benzoate (6)}

To a solution of $1 \mathrm{~g}$ ( $6.48 \mathrm{mmol}, 1$ equiv.) of 2,3-dihydroxybenzoic acid in $30 \mathrm{~mL}$ of acetone was added $2 \mathrm{~g}$ ( $14.5 \mathrm{mmol}, 2$ equiv.) of potassium carbonate and $1 \mathrm{~g}(3.24 \mathrm{mmol}, 0.5$ equiv.) of tetrabutylammonium iodide. The mixture was stirred at $25{ }^{\circ} \mathrm{C}$ for $1 \mathrm{~h}$. $3.6 \mathrm{~mL}(25.92 \mathrm{mmol}, 4$ equiv.) of 4-methoxybenzylchloride was added and stirred under reflux overnight. The resulting solution was concentrated under reduced pressure. The residue was purified by flash chromatography (Cyclohexane:AcOEt 4:1) to yield a white powder (1.93 g, 70\%). mp: $90{ }^{\circ} \mathrm{C}$ (litt. $108^{\circ} \mathrm{C}$ [41]) $\sqrt{\max }_{\text {: }}$ : 3066, 3032, 1706, 1610, 1581, 1509, 1241, 1174, $1020 \mathrm{~cm}^{-1} ;{ }^{1} \mathrm{H}$ NMR $\left(400 \mathrm{MHz}, \mathrm{CDCl}_{3}\right): \delta 3.79(\mathrm{~s}, 3 \mathrm{H}$, $\left.\mathrm{OCH}_{3}\right), 3.80\left(\mathrm{~s}, 3 \mathrm{H}, \mathrm{OCH}_{3}\right), 3.82\left(\mathrm{~s}, 3 \mathrm{H}, \mathrm{OCH}_{3}\right), 4.95\left(\mathrm{~s}, 2 \mathrm{H}, \mathrm{CH}_{2}\right), 5.04\left(\mathrm{~s}, 2 \mathrm{H}, \mathrm{CH}_{2}\right), 5.25\left(\mathrm{~s}, 2 \mathrm{H}, \mathrm{CH}_{2}\right)$, $6.77\left(\mathrm{~d}, J=8.6 \mathrm{~Hz}, 2 \mathrm{H}, \mathrm{H}_{\mathrm{ar}}\right), 6.87\left(\mathrm{~d}, J=8.7 \mathrm{~Hz}, 2 \mathrm{H}, \mathrm{H}_{\mathrm{ar}}\right), 6.90\left(\mathrm{~d}, J=8.6 \mathrm{~Hz}, 2 \mathrm{H}, \mathrm{H}_{\mathrm{ar}}\right), 7.05(\mathrm{t}, J=8.0 \mathrm{~Hz}$, $\left.1 \mathrm{H}, \mathrm{H}_{\mathrm{ar}}\right), 7.12\left(\mathrm{dd}, J=1.7,8.2 \mathrm{~Hz}, 1 \mathrm{H}, \mathrm{H}_{\mathrm{ar}}\right), 7.19\left(\mathrm{~d}, J=8.6 \mathrm{~Hz}, 2 \mathrm{H}, \mathrm{H}_{\mathrm{ar}}\right), 7.31-7.36\left(\mathrm{~m}, 5 \mathrm{H}, \mathrm{H}_{\mathrm{ar}}\right) \mathrm{ppm}$; 
${ }^{13} \mathrm{C} \mathrm{NMR}\left(100 \mathrm{MHz}, \mathrm{CDCl}_{3}\right): \delta 55.4\left(\mathrm{OCH}_{3}\right), 55.4\left(\mathrm{OCH}_{3}\right), 55.5\left(\mathrm{OCH}_{3}\right), 66.8\left(\mathrm{OCH}_{2}\right), 71.3\left(\mathrm{OCH}_{2}\right)$, $75.4\left(\mathrm{OCH}_{2}\right), 113.7\left(\mathrm{C}_{\mathrm{ar}}\right), 114.1\left(\mathrm{C}_{\mathrm{ar}}\right), 118.3\left(\mathrm{C}_{\mathrm{ar}}\right), 123.0\left(\mathrm{C}_{\mathrm{ar}}\right), 123.9\left(\mathrm{C}_{\mathrm{ar}}\right), 127.1\left(\mathrm{C}_{\mathrm{ar}}\right), 128.3\left(\mathrm{C}_{\mathrm{ar}}\right), 128.8$ $\left(\mathrm{C}_{\mathrm{ar}}\right), 129.5\left(\mathrm{C}_{\mathrm{ar}}\right), 129.8\left(\mathrm{C}_{\mathrm{ar}}\right), 130.3\left(\mathrm{C}_{\mathrm{ar}}\right), 130.4\left(\mathrm{C}_{\mathrm{ar}}\right), 148.5\left(\mathrm{C}_{\mathrm{ar}} \mathrm{O}\right), 153.0\left(\mathrm{C}_{\mathrm{ar}} \mathrm{O}\right), 159.5\left(\underline{C O C H}_{3}\right), 159.7$ $\left(\mathrm{COCH}_{3}\right), 159.7\left(\mathrm{COCH}_{3}\right), 166.5(\mathrm{C}=\mathrm{O})$ ppm; HRMS (ES+): exact mass calculated for $\mathrm{C}_{31} \mathrm{H}_{30} \mathrm{O}_{7} \mathrm{Na}$ : 537.1889. Found 537.1895.

\section{2,3-bis((4-methoxybenzyl)oxy)benzoic acid (4)}

To a solution of $500 \mathrm{mg}$ ( $0.97 \mathrm{mmol}, 1$ equiv.) of 6 in $12 \mathrm{~mL}$ of dioxane was added $4.9 \mathrm{~mL}$ ( $9.7 \mathrm{mmol}$, 10 equiv.) of sodium hydroxide $2 \mathrm{M}$. The reaction was stirred at $25^{\circ} \mathrm{C}$ for 3 days. The mixture was concentrated under reduced pressure. The residue was dissolved in water and an aqueous solution of $1 \mathrm{M} \mathrm{HCl}$ was added dropwise until $\mathrm{pH} 2$. The precipitate was filtrated and washed with hexane to yield a white powder $\left(1.93 \mathrm{~g}\right.$, quant.). mp: $110^{\circ} \mathrm{C}$ (litt. $\left.119^{\circ} \mathrm{C}[41]\right) \sqrt{\max }_{3}: 3004,1579,1512,1304,1246$, $1173 \mathrm{~cm}^{-1} ;{ }^{1} \mathrm{H}$ NMR $\left(400 \mathrm{MHz}, \mathrm{DMSO}-d_{6}\right): \delta 3.74\left(\mathrm{~s}, 3 \mathrm{H}, \mathrm{OCH}_{3}\right), 3.77\left(\mathrm{~s}, 3 \mathrm{H}, \mathrm{OCH}_{3}\right), 4.89\left(\mathrm{~s}, 2 \mathrm{H}, \mathrm{CH}_{2}\right)$, $5.10\left(\mathrm{~s}, 2 \mathrm{H}, \mathrm{CH}_{2}\right), 6.84\left(\mathrm{~d}, J=8.6 \mathrm{~Hz}, 2 \mathrm{H}, \mathrm{H}_{\mathrm{ar}}\right), 6.97\left(\mathrm{~d}, J=8.6 \mathrm{~Hz}, 2 \mathrm{H}, \mathrm{H}_{\mathrm{ar}}\right), 7.12\left(\mathrm{t}, J=7.8 \mathrm{~Hz}, 1 \mathrm{H}, \mathrm{H}_{\mathrm{ar}}\right)$, $7.19\left(\mathrm{dd}, J=1.7,7.8 \mathrm{~Hz}, 1 \mathrm{H}, \mathrm{H}_{\mathrm{ar}}\right), 7.27\left(\mathrm{~d}, J=8.6 \mathrm{~Hz}, 2 \mathrm{H}, \mathrm{H}_{\mathrm{ar}}\right), 7.33\left(\mathrm{dd}, J=1.7,7.8 \mathrm{~Hz}, 1 \mathrm{H}, \mathrm{H}_{\mathrm{ar}}\right), 7.42(\mathrm{~d}$, $\left.J=8.6 \mathrm{~Hz}, 2 \mathrm{H}, \mathrm{H}_{\mathrm{ar}}\right)$ ppm.; ${ }^{13} \mathrm{C}$ NMR $\left(100 \mathrm{MHz}, \mathrm{DMSO}-d_{6}\right): \delta 55.1\left(\mathrm{OCH}_{3}\right), 55.2\left(\mathrm{OCH}_{3}\right), 70.0\left(\mathrm{OCH}_{2}\right)$, 74.4 $\left(\mathrm{OCH}_{2}\right), 113.5\left(\mathrm{C}_{\mathrm{ar}}\right), 113.9\left(\mathrm{C}_{\mathrm{ar}}\right), 117.1\left(\mathrm{C}_{\mathrm{ar}}\right), 121.4\left(\mathrm{C}_{\mathrm{ar}}\right), 124.1\left(\mathrm{C}_{\mathrm{ar}}\right), 128.0\left(\mathrm{C}_{\mathrm{ar}}\right), 128.7\left(\mathrm{C}_{\mathrm{ar}}\right), 129.5$ $\left(\mathrm{C}_{\mathrm{ar}}\right), 129.7\left(\mathrm{C}_{\mathrm{ar}}\right), 130.0\left(\mathrm{C}_{\mathrm{ar}}\right), 146.6\left(\mathrm{C}_{\mathrm{ar}} \mathrm{O}\right), 152.3\left(\mathrm{C}_{\mathrm{ar}} \mathrm{O}\right), 159.0\left(\mathrm{COCH}_{3}\right), 159.2\left(\mathrm{COCH}_{3}\right), 167.5(\mathrm{C}=\mathrm{O})$ ppm; HRMS (ES+): exact mass calculated for $\mathrm{C}_{23} \mathrm{H}_{22} \mathrm{O}_{6} \mathrm{Na}$ : 417.1314. Found 417.1317.

\section{3-((4-methoxybenzyl)oxy)-2-methyl-4H-pyran-4-one (5)}

To a solution of $500 \mathrm{mg}$ ( $3.96 \mathrm{mmol}, 1$ equiv.) of maltol in $5 \mathrm{~mL}$ of DMF was added $547 \mathrm{mg}$ (3.96 mmol, 1 equiv.) of potassium carbonate and $0.6 \mathrm{~mL}$ (4.4 mmol, 1.1 equiv.) of 4-methoxybenzyl chloride. The reaction mixture was stirred at $60{ }^{\circ} \mathrm{C}$ for $5 \mathrm{~h}$. The resulting solution was allowed to return to room temperature. The solvent was evaporated and water was added. The aqueous phase was washed with DCM $(3 \times 10 \mathrm{~mL})$. The organic phases were washed with water $(2 \times 10 \mathrm{~mL})$, dried with $\mathrm{Na}_{2} \mathrm{SO}_{4}$, filtrated and concentrated. The residue was purified by flash chromatography (AcOEt:Cyclohexane 7:3) to yield a yellow oil $(650 \mathrm{mg}, 65 \%) .{ }^{1} \mathrm{H} \mathrm{NMR}\left(400 \mathrm{MHz}, \mathrm{CDCl}_{3}\right): \delta 2.05\left(\mathrm{~s}, 3 \mathrm{H}, \mathrm{CH}_{3}\right), 3.80(\mathrm{~s}$, $\left.3 \mathrm{H}, \mathrm{OCH}_{3}\right), 5.10\left(\mathrm{~s}, 2 \mathrm{H}, \mathrm{CH}_{2}\right), 6.36(\mathrm{~d}, J=5.64 \mathrm{~Hz}, 1 \mathrm{H}, \mathrm{CH}-\mathrm{C}=\mathrm{O}), 6.85\left(\mathrm{~d}, J=8.6 \mathrm{~Hz}, 2 \mathrm{H}, \mathrm{H}_{\mathrm{ar}}\right), 7.30$ $\left(\mathrm{d}, J=8.6 \mathrm{~Hz}, 2 \mathrm{H}, \mathrm{H}_{\mathrm{ar}}\right), 7.58(\mathrm{~d}, J=5.64 \mathrm{~Hz}, 1 \mathrm{H}, \mathrm{CH}-\mathrm{CO}) \mathrm{ppm} ;{ }^{13} \mathrm{C} \mathrm{NMR}\left(100 \mathrm{MHz}, \mathrm{CDCl}_{3}\right): \delta 14.8$ $\left(\mathrm{CH}_{3}\right), 55.2\left(\mathrm{OCH}_{3}\right), 73.1\left(\mathrm{OCH}_{2}\right), 113.7\left(2 \mathrm{C}_{\mathrm{ar}}\right), 117.1\left(\mathrm{C}_{\mathrm{ar}}\right), 129.0\left(\mathrm{C}_{\mathrm{ar}}\right), 130.7\left(2 \mathrm{C}_{\mathrm{ar}}\right), 143.5(\underline{\mathrm{C}}-\mathrm{CO}), 153.3$ $\left(\underline{C}^{2} H_{3}\right), 159.7(\underline{\mathrm{CH}}-\mathrm{CO}), 159.8(\underline{\mathrm{CH}}-\mathrm{C}=\mathrm{O}), 175.1(\mathrm{C}=\mathrm{O})$ ppm. HRMS (ES+): exact mass calculated for $\mathrm{C}_{14} \mathrm{H}_{14} \mathrm{O}_{4} \mathrm{Na}$ : 269.0790. Found 269.0791.

\section{N,N'-(piperazine-1,4-diylbis(propane-3,1-diyl))bis(2,3-bis((4-methoxybenzyl)oxy)benzamide) (7)}

To a solution, under argon, of $0.25 \mathrm{~mL}$ (1.2 mmol, 1 equiv.) 1,4-bis(3-aminopropyl)piperazine 3 in $100 \mathrm{~mL}$ of DCM was added $1 \mathrm{~g}$ ( $2.5 \mathrm{mmol}, 2.1$ equiv. $)$ of $4,510 \mathrm{mg}(2.65 \mathrm{mmol}, 2.2$ equiv. $)$ of EDCI and $370 \mathrm{mg}$ ( $2.41 \mathrm{mmol}, 2$ equiv.) of $\mathrm{HOBt}$. The solution was stirred at $25^{\circ} \mathrm{C}$ overnight. The resulting solution was concentrated under reduced pressure. The residue was purified by flash chromatography (DCM:MeOH 9:1) to yield a yellow oil $(685 \mathrm{mg}, 60 \%) .{ }^{1} \mathrm{H}$ NMR $\left(400 \mathrm{MHz}, \mathrm{CDCl}_{3}\right): \delta 1.52-1.69(\mathrm{~m}$, $\left.4 \mathrm{H}, \mathrm{CH}_{2}\right), 1.69\left(\mathrm{~m}, 8 \mathrm{H}, \mathrm{CH}_{2-p i p}\right), 3.33\left(\mathrm{q}, \mathrm{J}=6.6 \mathrm{~Hz}, 4 \mathrm{H}, \mathrm{CH}_{2}\right), 2.25\left(\mathrm{t}, \mathrm{J}=7.2 \mathrm{~Hz}, 4 \mathrm{H}, \mathrm{CH}_{2}\right), 3.77(\mathrm{~s}, 6 \mathrm{H}$, $\left.\mathrm{OCH}_{3}\right), 3.82\left(\mathrm{~s}, 6 \mathrm{H}, \mathrm{OCH}_{3}\right), 4.97\left(\mathrm{~s}, 4 \mathrm{H}, \mathrm{OCH}_{2}\right), 5.06\left(\mathrm{~s}, 4 \mathrm{H}, \mathrm{OCH}_{2}\right), 6.81\left(\mathrm{~d}, \mathrm{~J}=8.6 \mathrm{~Hz}, 4 \mathrm{H}, \mathrm{H}_{\mathrm{ar}}\right), 6.93(\mathrm{~d}$, $\left.\mathrm{J}=8.6 \mathrm{~Hz}, 4 \mathrm{H}, \mathrm{H}_{\mathrm{ar}}\right), 7.11-7.13\left(\mathrm{~m}, 4 \mathrm{H}, \mathrm{H}_{\mathrm{ar}}\right), 7.23\left(\mathrm{~d}, \mathrm{~J}=8.6 \mathrm{~Hz}, 4 \mathrm{H}, \mathrm{H}_{\mathrm{ar}}\right), 7.38\left(\mathrm{~d}, \mathrm{~J}=8.6 \mathrm{~Hz}, 4 \mathrm{H}, \mathrm{H}_{\mathrm{ar}}\right)$, $7.67\left(\mathrm{dd}, \mathrm{J}=6.0,3.6 \mathrm{~Hz}, 2 \mathrm{H}, \mathrm{H}_{\mathrm{ar}}\right), 8.16(\mathrm{t}, \mathrm{J}=8.0 \mathrm{~Hz}, 2 \mathrm{H}, \mathrm{NH}) \mathrm{ppm} .{ }^{13} \mathrm{C} \mathrm{NMR}\left(100 \mathrm{MHz}, \mathrm{CDCl}_{3}\right): \delta 26.4$ $\left(\mathrm{CH}_{2}\right), 38.5\left(\mathrm{CH}_{2}\right), 53.0\left(\mathrm{CH}_{2 \text {-pip }}\right), 55.4\left(\mathrm{OCH}_{3}\right), 55.5\left(\mathrm{OCH}_{3}\right), 56.4\left(\mathrm{CH}_{2}\right), 71.2\left(\mathrm{OCH}_{2}\right), 76.1\left(\mathrm{OCH}_{2}\right)$, $114.0\left(\mathrm{C}_{\mathrm{ar}}\right), 114.2\left(\mathrm{C}_{\mathrm{ar}}\right), 116.9\left(\mathrm{C}_{\mathrm{ar}}\right), 123.2\left(\mathrm{C}_{\mathrm{ar}}\right), 124.4\left(\mathrm{C}_{\mathrm{ar}}\right), 128.0\left(\mathrm{C}_{\mathrm{ar}}\right), 128.7\left(\mathrm{C}_{\mathrm{ar}}\right), 128.8\left(\mathrm{C}_{\mathrm{ar}}\right), 129.6$ $\left.\left(\mathrm{C}_{\mathrm{ar}}\right), 130.7\left(\mathrm{C}_{\mathrm{ar}}\right), 146.8(\mathrm{Car}), 152.0\left(\mathrm{C}_{\mathrm{ar}} \mathrm{O}\right), 159.8(\underline{\mathrm{COCH}})_{3}\right), 160.0\left(\underline{\mathrm{COCH}}_{3}\right), 165.3(\mathrm{C}=\mathrm{O}) \mathrm{ppm}$; HRMS (ES+): exact mass calculated for $\mathrm{C}_{56} \mathrm{H}_{65} \mathrm{~N}_{4} \mathrm{O}_{10}$ : 953.4701. Found 953.4700 . 
$0.6 \mathrm{~mL}$ ( $2.7 \mathrm{mmol}, 1$ equiv.) of 1,4-bis(3-aminopropyl)piperazine 3 was dissolved in $120 \mathrm{~mL}$ of a $\mathrm{MeOH} / \mathrm{H}_{2} \mathrm{O}(2 / 1)$ solution. $2 \mathrm{~g}(8.1 \mathrm{mmol}, 3$ equiv. $)$ of 5 and $250 \mathrm{mg}(6.2 \mathrm{mmol}, 2.3$ equiv.) of sodium hydroxide were added. The reaction mixture was stirred under reflux for 3 days. The resulting solution was washed with $\mathrm{DCM}$, and the organic layers were combined and dried over $\mathrm{Na}_{2} \mathrm{SO}_{4}$ and concentrated. The resulting mixture was treated with $\mathrm{HCl} 3 \mathrm{M}$ in $\mathrm{MeOH}$, evaporated, and triturated with ether. The solid formed was washed with ether and DCM to yield a white solid (1.2 g, $70 \%)$. mp: $100{ }^{\circ} \mathrm{C} .{ }^{1} \mathrm{H}$ NMR $(400 \mathrm{MHz}, \mathrm{MeOH}-\mathrm{d} 4): \delta 2.02-2.14\left(\mathrm{~m}, 4 \mathrm{H}, \mathrm{CH}_{2}\right), 2.49\left(\mathrm{~s}, 6 \mathrm{H}, \mathrm{CH}_{3}\right), 2.83-3.08(\mathrm{~m}, 12 \mathrm{H}$, $\left.\mathrm{CH}_{2 \text {-pip }}, \mathrm{CH}_{2}\right), 3.80\left(\mathrm{~s}, 6 \mathrm{H}, \mathrm{OCH}_{3}\right), 4.40\left(\mathrm{t}, \mathrm{J}=7.5 \mathrm{~Hz}, 4 \mathrm{H}, \mathrm{CH}_{2}\right), 5.15\left(\mathrm{~s}, 4 \mathrm{H}, \mathrm{OCH}_{2}\right), 6.92(\mathrm{~d}, \mathrm{~J}=8.6$ $\left.\mathrm{Hz}, 4 \mathrm{H}, \mathrm{H}_{\mathrm{ar}}\right), 7.16(\mathrm{~d}, \mathrm{~J}=7.1 \mathrm{~Hz}, 2 \mathrm{H}, \mathrm{CH}), 7.34\left(\mathrm{~d}, \mathrm{~J}=8.6 \mathrm{~Hz}, 4 \mathrm{H}, \mathrm{H}_{\mathrm{ar}}\right), 8.35(\mathrm{~d}, \mathrm{~J}=7.1 \mathrm{~Hz}, 2 \mathrm{H}, \mathrm{CH})$ ppm; ${ }^{13} \mathrm{C}$ NMR $\left(100 \mathrm{MHz}, \mathrm{MeOH}-\mathrm{d}_{4}\right): \delta 13.5\left(\mathrm{CH}_{3}\right), 26.8\left(\mathrm{CH}_{2}\right), 52.0\left(\mathrm{CH}_{2}\right), 54.0\left(\mathrm{CH}_{2}\right), 54.1\left(\mathrm{CH}_{2-\text { pip }}\right)$, $55.8\left(\mathrm{OCH}_{3}\right), 75.2\left(\mathrm{OCH}_{2}\right), 114.9\left(\mathrm{C}_{\mathrm{ar}}\right), 115.4\left(\mathrm{C}_{\mathrm{ar}}\right), 129.7\left(\mathrm{C}_{\mathrm{ar}}\right), 132.0\left(\mathrm{C}_{\mathrm{ar}}\right), 142.5\left(\mathrm{CCH}_{3}\right), 145.7(\mathrm{CH})$, $149.0(\mathrm{CO}), 161.6\left(\mathrm{COCH}_{3}\right), 169.4(\mathrm{C}=\mathrm{O}) \mathrm{ppm}$; HRMS (ES+): exact mass calculated for $\mathrm{C}_{38} \mathrm{H}_{49} \mathrm{~N}_{4} \mathrm{O}_{6}$ : 657.3652. Found 657.3657.

\section{N,N'-(piperazine-1,4-diylbis(propane-3,1-diyl))bis(2,3-dihydroxybenzamide) (1)}

$100 \mathrm{mg}$ ( $0.15 \mathrm{mmol}, 1$ equiv.) of 7 was dissolved in $20 \mathrm{~mL}$ of a MeOH with $1 \mathrm{~mL}$ DCM. Using the $\mathrm{H}$-cube, the resulting solution was put under $\mathrm{H}_{2}$ with $20 \% \mathrm{Pd}(\mathrm{OH})_{2} / \mathrm{C}$ at $60{ }^{\circ} \mathrm{C}$ with a flow rate of $1 \mathrm{~mL} \cdot \mathrm{min}^{-1}$. The resulting solution was evaporated to yield a solid $(50 \mathrm{mg}, 90 \%) . \mathrm{mp}: 180{ }^{\circ} \mathrm{C} .{ }^{1} \mathrm{H}$ NMR $\left(400 \mathrm{MHz}, \mathrm{MeOH}-\mathrm{d}_{4}\right): \delta 1.92-1.99\left(\mathrm{~m}, 4 \mathrm{H}, \mathrm{CH}_{2}\right), 2.92\left(\mathrm{t}, J=7.5 \mathrm{~Hz}, 4 \mathrm{H}, \mathrm{CH}_{2}\right), 3.10-3.14(\mathrm{~m}, 8 \mathrm{H}$, $\left.\mathrm{CH}_{2 \text {-pip }}\right), 3.49\left(\mathrm{t}, J=6.7 \mathrm{~Hz}, 4 \mathrm{H}, \mathrm{CH}_{2}\right), 6.73\left(\mathrm{t}, J=8.0 \mathrm{~Hz}, 2 \mathrm{H}, \mathrm{H}_{\mathrm{ar}}\right), 6.94\left(\mathrm{dd}, J=1.5,8.0 \mathrm{~Hz}, 2 \mathrm{H}, \mathrm{H}_{\mathrm{ar}}\right)$, $7.21\left(\mathrm{dd}, J=1.5,8.0 \mathrm{~Hz}, 2 \mathrm{H}, \mathrm{H}_{\mathrm{ar}}\right) \mathrm{ppm} ;{ }^{13} \mathrm{C} \mathrm{NMR}\left(100 \mathrm{MHz}, \mathrm{MeOH}-\mathrm{d}_{4}\right): \delta 26.2\left(\mathrm{CH}_{2}\right), 37.8\left(\mathrm{CH}_{2}\right), 51.6$ $\left(\mathrm{CH}_{2-\text { pip }}\right), 55.8\left(\mathrm{CH}_{2}\right), 116.9\left(\mathrm{C}_{\mathrm{ar}}\right), 118.9\left(\mathrm{C}_{\mathrm{ar}}\right), 119.7\left(\mathrm{C}_{\mathrm{ar}}\right), 119.7\left(\mathrm{C}_{\mathrm{ar}}\right), 121.8\left(\mathrm{C}_{\mathrm{ar}}\right), 147.4(\mathrm{COH}), 150.0$ $(\mathrm{COH}), 171.8(\mathrm{C}=\mathrm{O})$ ppm; HRMS (ES+): exact mass calculated for $\mathrm{C}_{24} \mathrm{H}_{33} \mathrm{~N}_{4} \mathrm{O}_{6}$ : 473.2400. Found 473.2413. LCMS: tr $8.8 \mathrm{~min}(2 \% \mathrm{~A} / 98 \% \mathrm{~B}), 190 \mathrm{~nm}$ : purity $>96 \%$.

\section{1,1'-(piperazine-1,4-diylbis(propane-3,1-diyl))bis(3-hydroxy-2-methylpyridin-4(1H)-one) (2)}

$1 \mathrm{~g}(1.5 \mathrm{mmol}, 1$ equiv.) of 8 was dissolved in $100 \mathrm{~mL}$ of a MeOH. Using the $\mathrm{H}$-cube, the resulting solution was put under $\mathrm{H}_{2}$ with $20 \% \mathrm{Pd}(\mathrm{OH})_{2} / \mathrm{C}$ at $60{ }^{\circ} \mathrm{C}$ with a flow rate of $1 \mathrm{~mL} \cdot \mathrm{min}^{-1}$. The resulting solution was evaporated to yield a red solid (600 mg, 90\%). mp: $260{ }^{\circ} \mathrm{C} .{ }^{1} \mathrm{H} \mathrm{NMR}\left(400 \mathrm{MHz}, \mathrm{MeOH}-\mathrm{d}_{4}\right)$ : 反 2.31-2.35 (m, 4H, $\left.\mathrm{CH}_{2}\right), 2.69\left(\mathrm{~s}, 6 \mathrm{H}, \mathrm{CH}_{3}\right), 3.13-3.20\left(\mathrm{~m}, 4 \mathrm{H}, \mathrm{CH}_{2}\right), 3.47-3.54\left(\mathrm{~m}, 8 \mathrm{H}, \mathrm{CH}_{2-p i p}\right), 4.52(\mathrm{t}, J$ $\left.=7.7 \mathrm{~Hz}, 4 \mathrm{H}, \mathrm{CH}_{2}\right), 7.14\left(\mathrm{~d}, J=6.9 \mathrm{~Hz}, 2 \mathrm{H}, \mathrm{H}_{\mathrm{ar}}\right), 8.24\left(\mathrm{~d}, J=6.9 \mathrm{~Hz}, 2 \mathrm{H}, \mathrm{H}_{\mathrm{ar}}\right) \mathrm{ppm} ;{ }^{13} \mathrm{C} \mathrm{NMR}(100 \mathrm{MHz}$, MeOH-d $\left.)_{4}\right): \delta 12.9\left(\mathrm{CH}_{3}\right), 26.0\left(\mathrm{CH}_{2}\right), 50.4\left(\mathrm{CH}_{2}\right), 54.2\left(\mathrm{CH}_{2-p i p}\right), 54.6\left(\mathrm{CH}_{2}\right), 111.9\left(\mathrm{C}_{\mathrm{ar}}\right), 139.2\left(\mathrm{CCH}_{3}\right)$, $143.4\left(\mathrm{C}_{\mathrm{ar}}\right), 145.3(\underline{\mathrm{COH}}), 159.9(\mathrm{C}=\mathrm{O}) \mathrm{ppm}$; HRMS (ES+): exact mass calculated for $\mathrm{C}_{22} \mathrm{H}_{33} \mathrm{~N}_{4} \mathrm{O}_{4}$ : 417.2502. Found 417.2500. LCMS: tr $0.9 \mathrm{~min}(98 \% \mathrm{~A} / 2 \% \mathrm{~B}), 190 \mathrm{~nm}$ : purity $>92 \%$.

\subsection{Physicochemical Studies}

\subsubsection{Generalities}

All commercial reagents used were of the highest purity $(>99 \%)$ and were used without further purification. All stock solutions were used fresh. Because of the poor solubility of the chelators in aqueous media, all experiments were monitored in $\mathrm{H}_{2} \mathrm{O} / \mathrm{DMSO}$ media $\left(\mathrm{v} / \mathrm{v}=50: 50 ; \mathrm{x}_{\text {DMSO }}=0.2\right)$.

Ligand and metal solutions were prepared in the concentration range between $10^{-4}$ to $2 \times$ $10^{-3} \mathrm{~mol} \cdot \mathrm{L}^{-1}$. The ionic strength was kept constant $(\mathrm{I}=0.1)$ by addition of potassium chloride (Prolabo) of the highest purity ( $>99 \%)$. The titrating solutions of carbonate-free base $\mathrm{KOH}$ and hydrochloric acid $0.1 \mathrm{M}$ were prepared from standardized $1 \mathrm{M}$ solutions (Prolabo). All solutions were prepared with glass-distilled, deionized water degassed by argon saturation to remove all dissolved $\mathrm{CO}_{2}$ and with DMSO, spectrophotometric grade. Protometric titrations were carried out with an automatic titrator composed of a microprocessor burette (Metrohm Dosimat 665), a glass electrode (metrohm AG 9101) with an incorporated $\mathrm{Ag} / \mathrm{AgCl}$ reference (filled with $\mathrm{KCl} 3 \mathrm{~mol} \cdot \mathrm{L}^{-1}$ and a $\mathrm{pH}$ meter (Metrohm 713) connected to a computer. The combined electrode has a very low alkaline error. The titration was fully 
automated. All measurements were performed within a thermoregulated cell at $25^{\circ} \mathrm{C}$ under an argon stream to avoid the dissolution of carbon dioxide.

For a classical titration, a total of 120 to 150 points (volume of titrant, $\mathrm{pH}$ ) was recorded. All equilibrium measurements were carried out in $4.00 \mathrm{~mL}$ sample volumes with magnetic stirring. The electrode slope was determined with two commercial buffers ( $\mathrm{pH} 4$ and $\mathrm{pH} 10$ ) and checked by titration with an $\mathrm{HCl}$ solution at exactly $5.010^{-3} \mathrm{~mol} \cdot \mathrm{L}^{-1}$. No correction was necessary in the $\mathrm{pH}$ range of 2-12.5. The titrant, a carbonate-free KOH solution (Normadose, Merck, Darmstadt, Germany), was standardized against a $10^{-2} \mathrm{~mol} \cdot \mathrm{L}^{-1}$ potassium hydrogen phthalate solution by $\mathrm{pH}$ potentiometry. The ionic product of the $\mathrm{H}_{2} \mathrm{O} / \mathrm{DMSO}$ was determined with the titration of hydrogen phthalate solutions, under our experimental conditions. A value of 16.0 was determined and used in the calculations. Consequently, the usable $\mathrm{pH}$ range is between 2 and 14 .

$\mathrm{UV}$-visible spectra were recorded after each base addition at $\left(25 \pm 0.1^{\circ} \mathrm{C}\right)$. All spectra were recorded using a Shimadzu UV-2401-PC spectrophotometer equipped with a standard syringe shipper and a temperature-controlled TCC-240A cell holder. The experiments were monitored in the concentration range used for the $\mathrm{pH}$ titration; averages of 25 spectra were recorded in the $\mathrm{pH}$ range from 2 to 12 .

\subsubsection{ESI-MS}

All experiments were performed on a hybrid tandem quadrupole/time-of-flight (Q-TOF) instrument, equipped with a pneumatically assisted electrospray (Z-spray) ion source operated in positive or negative mode (SYNAPT G2si, Waters). The electrospray potential was set to $0.5 \mathrm{kV}$ in positive and $2 \mathrm{kV}$ in negative ion mode, and the extraction cone voltage was set to $40 \mathrm{~V}$ to obtain optimized mass spectra. The FeL solutions were prepared in similar conditions to those set out for the potentiometric study without ionic strength. The stoichiometries of the molecular associations were determined in accordance with the greater isotopic peak (corresponding to species with ${ }^{56} \mathrm{Fe}$ ), and further checked by simulating the different parts of the spectrum with the Isopro 3.0 software [42]. The differences between the experimental and calculated $\mathrm{m} / \mathrm{z}$ values were less than or equal to 0.1 unit.

\subsubsection{Computation}

The protonation constants of the ligand and the overall stability constants $\left(\beta_{\mathrm{mlh}}\right)$ of the metal complexes were calculated from nonlinear least-square refinements of potentiometric titration with the general computation program PROTAF [43].

The global protonation constant $\beta_{\mathrm{m} 1 \mathrm{~h}}$

$$
\begin{gathered}
\mathrm{mM}+\mathrm{lL}+\mathrm{hH} \leftrightharpoons \mathrm{M}_{\mathrm{m}} \mathrm{L}_{1} \mathrm{H}_{\mathrm{h}}, \\
\beta_{\mathrm{m} 1 \mathrm{~h}}=\frac{\left[\mathrm{M}_{\mathrm{m}} \mathrm{L}_{1} \mathrm{H}_{\mathrm{h}}\right]}{[\mathrm{M}]^{\mathrm{m}}[\mathrm{L}]^{1}[\mathrm{H}]^{\mathrm{h}}},
\end{gathered}
$$

in which $m, l$, and $h$ are values in the general complex formula $\left[\mathrm{M}_{\mathrm{m}} \mathrm{L}_{1} \mathrm{H}_{\mathrm{h}}\right] . \mathrm{M}, \mathrm{L}$, and $\mathrm{H}$ correspond to the metal ion, the ligand, and the protons, respectively. For the sake of clarity, charges are omitted. The computer program HYSS was used to obtain the species distribution curves $[44,45]$.

\subsection{4. $\mathrm{pFe}$ Determination}

For ligands that have low water solubility, the classical methodology to determine pFe consists of determining the overall formation constant $(\log \beta)$ values in a water/solvent mixture by varying the molar fraction of the used solvent ( $x_{\text {DMSO }}$ ). Then, the values are extrapolated in a pure $\mathrm{H}_{2} \mathrm{O}$ medium by taking into account a linear dependence approximation between $\log \beta$ and the molar fraction of the solvent ( $\mathrm{x}_{\mathrm{DMSO}}$ ) [46]. The complex and ligand insolubility in a water/DMSO medium for $\mathrm{x}_{\mathrm{DMSO}}<0.2$ renders such a methodology irrelevant to the pFe determination in the case of Fe-1 and Fe-2 systems. This problem can be overcome by performing $\mathrm{pFe}$ calculations with data collected in a $\mathrm{H}_{2} \mathrm{O} / \mathrm{DMSO}$ medium $\left(\mathrm{x}_{\mathrm{DMSO}}=0.2\right)$ at a $\mathrm{pH}$ corresponding to the same $\left[\mathrm{OH}^{-}\right] /\left[\mathrm{H}_{3} \mathrm{O}^{+}\right]$ratio as that in pure water 
(pH 7.45) [47]. For $\mathrm{x}_{\mathrm{DMSO}}$ equal to 0.2 , the $\mathrm{pH}$ scale is extended from 0 to 16.0 , and a neutral solution has a $\mathrm{pH}$ value of 8.05. Consequently, a $\mathrm{pH}$ of 7.45 in water corresponds to 8.44 in a $\mathrm{H}_{2} \mathrm{O} / \mathrm{DMSO}$ medium $\left(\mathrm{x}_{\mathrm{DMSO}}=0.2\right)$. pFe calculations were monitored by using the HYSS software $[44,45]$.

\subsection{Biological Evaluation and Siderophore-Like Activity}

\subsubsection{Bacterial Strains}

The following strains were used for testing antibacterial susceptibility: Pseudomonas aeruginosa DSM 1117, and for siderophore-like activity, P. aeruginosa PAO1 as a wild type strain producing pyoverdine, and P. aeruginosa PAD07, a mutant strain, which does not produce pyoverdine or pyochelin, were used.

\subsubsection{Antibacterial Activity of 1 and 2}

The different bacterial strains were incubated overnight at $35^{\circ} \mathrm{C}$ in tryptic soy broth and streaked on tryptic soy agar. The inocula were then prepared according to the recommendations of CLSI (Clinical and Laboratory Standards Institute) and the Mueller-Hinton micro-dilution technique (MH, $\mathrm{pH} 7.3$ ) using a concentration range of 0.25 to $512 \mathrm{mgL}^{-1}$. These concentrations were obtained by dilutions from a stock solution of the tested product prepared in DMSO. Ciprofloxacin (Sigma Aldrich) in water was used as a control. The minimum inhibitory concentration (MIC) was determined visually and corresponds to the lowest concentration for which the wells are clear.

\subsubsection{Cytotoxicity}

Compounds cytotoxicity was evaluated in a human hepatoma cell line (HepG2 from ECACC, MERCK) cultured in $75 \mathrm{~cm}^{2}$ sterile flasks in modified Dulbecco's Modified Eagle's Medium supplemented with $10 \%$ fetal bovine serum (Gibco) in a humidified atmosphere of $5 \%$ carbon dioxide at $37^{\circ} \mathrm{C}$. Concentrations of the compounds in the range $0-100 \mu \mathrm{M}$ were added to cells. The vehicle (DMSO) was used as control. After a $48 \mathrm{~h}$ incubation period, cell viability was determined with the CellTiter-Glo ${ }^{\circledR}$ Luminescent Cell Viability Assay (Promega), according to the manufacturer's protocol. Cell viability was expressed as the percentage of Relative Light Units (RLU).

\subsubsection{Bacterial Growth under Restricted Iron Medium and Potential Siderophore-Like Activity}

The medium used was the succinate minimum medium ( $\mathrm{SMM}, \mathrm{pH}=7$ ). This corresponds to a depleted iron medium and is obtained by mixing a solution of $6.0 \mathrm{~g} \cdot \mathrm{L}^{-1}$ of $\mathrm{K}_{2} \mathrm{HPO}_{4}$, a solution of 3.0 g.L. $\mathrm{L}^{-1}$ of $\mathrm{KH}_{2} \mathrm{PO}_{4}$, a solution containing 1.0 g.L $\mathrm{L}^{-1}$ of $\left.\mathrm{NH}_{4}\right)_{2} \mathrm{SO}_{4}$, a solution of $0.2 \mathrm{~g} . \mathrm{L}^{-1}$ of $\mathrm{MgSO}_{4} \cdot 7 \mathrm{H}_{2} \mathrm{O}$, and a solution of $4.0 \mathrm{~g} . \mathrm{L}^{-1}$ of sodium succinate in PPI water (distilled water, sterile at $\mathrm{pH}=7.0$ ). This method simulates the conditions of development of bacteria in a depleted iron medium [40]. Our compounds were evaluated on this medium with or without addition of $\mathrm{FeCl}_{3}$ (Sigma Aldrich). For 1, the $\mathrm{FeCl}_{3}$ concentration in wells was fixed at $67 \mu \mathrm{M}$, and those of $\mathbf{1}$ were ranged from $2.109 \mu \mathrm{M}$ to $270 \mu \mathrm{M}$ (molecular ratio from 0.03125 to 4). As for 2, the $\mathrm{FeCl}_{3}$ concentration in wells was fixed at $65 \mu \mathrm{M}$, and those of 2 were ranged from $2.039 \mu \mathrm{M}$ to $260 \mu \mathrm{M}$ (molecular ratio from 0.03125 to 4). In a 96-well plate, $5 \mu \mathrm{L}$ of each dilution of the tested products was distributed with $5 \mu \mathrm{L}$ of sterile water or $5 \mu \mathrm{L}$ of a sterile aqueous $\mathrm{FeCl}_{3}$ solution. Each well was then supplemented with $220 \mu \mathrm{L}$ of SMM and $20 \mu \mathrm{L}$ of a $0.5 \mathrm{McF}$ arland bacterial suspension. The plates were incubated for $24 \mathrm{~h}$ at $37^{\circ} \mathrm{C}$. Absorbance (OD) was then measured using a Multiskan Ex reader (Thermo Labsystems, Issy les Moulineaux, France) at $600 \mathrm{~nm}$ to observe bacterial growth. The references were obtained by making wells containing the medium and the molecule, without inoculum, in order to measure the absorbance of our compounds at $600 \mathrm{~nm}$. Controls, containing the bacterial strains in SMM, without siderophore and supplemented or not with Fe (III), were also carried out. The experiments were repeated three times. Statistical analyses were carried out using the Mann-Whitney test page of Vassarstats website. A $p$ value below 0.05 was considered as significant [48]. 


\section{Conclusions}

We have synthesized two iron chelators $\mathbf{1}$ and $\mathbf{2}$ in four steps for $\mathbf{1}$ and three steps for $\mathbf{2}$ with an average yield of $40 \%$. Physicochemical studies highlighted the great affinity of these two ligands towards Fe(III). For both, the pFe values calculated with the formation constants exceed 20. The ligand $\mathbf{1}(\mathrm{pFe}=28.04)$ has an iron-chelating ability higher than the ligand $\mathbf{2}(\mathrm{pFe}=24.38)$ and the Pvd $(\mathrm{pFe}=$ 27), the main endogenous siderophore of $P$. aeruginosa. In physiological $\mathrm{pH}, \mathbf{1}$ forms $2: 3$ complexes with iron, whereas two species $\mathrm{Fe}_{2}(2)_{2} \mathrm{H}_{-1}$ or $\mathrm{Fe}_{2}(2)_{2} \mathrm{H}_{-2}$, corresponding to the deprotonation of $\mathrm{Fe}_{2}(2)_{2}$ are observed for $\mathbf{2}$. Both compounds have shown no antibacterial activities. The ligands $\mathbf{1}$ and $\mathbf{2}$ significantly increased the P. aeruginosa (PAD07, PAO1 strains) growth in iron-supplemented SMM. These results suggest that $\mathbf{1}$ and $\mathbf{2}$ could be internalized by the bacteria. The difference of bacterial growth for P. aeruginosa PAO1 compared to P. aeruginosa PAD07, in iron supplemented SMM, with the addition of $\mathbf{1}$ or $\mathbf{2}$, could be due to a Pvd's additional effect in iron transport. The greater growth effect of 1 compared to 2 could be partly explained in terms of an iron chelator property. According to these data, we used these iron piperazine-based chelators $\mathbf{1}$ and $\mathbf{2}$ to internalize toxic metal such as gallium. Unfortunately, the corresponding Ga(III)-1 and $\mathbf{2}$ complexes showed no antibacterial activity against P. aeruginosa DSM 1117 strain. However, ligands 1 and $\mathbf{2}$ could be used to promote the transport of antibiotics in Pseudomonas species.

Supplementary Materials: The following are available online at http://www.mdpi.com/1424-8247/12/4/160/s1.

Author Contributions: The project was conceptualized by A.D.-K., P.S. and P.L. was in charge of synthesis and structural characterization of all the described compounds. Physico-chemical studies were carried out by I.D.-O. and P.V. under the supervision of L.D. Siderophore and antibacterial activities were carried out by P.L. under the supervision of C.M. Cytotoxicity assays were realized by A.B., P.L., A.D.-K., I.D.-O., L.D., N.T., P.S. wrote the manuscript. The project was under the supervision of P.S.

Funding: This research was funded by DGA and the Hauts-de-France region.

Acknowledgments: The authors thank the DGA for financial support of this study. Pauline Loupias was the recipient of a Grant from DGA (Direction Générale de l'Armement, Ministère de la Défense, France) and the Hauts-de-France region.

Conflicts of Interest: The authors declare no conflict of interest. The funders had no role in the design of the study; in the collection, analyses, or interpretation of data; in the writing of the manuscript, or in the decision to publish the results.

\section{References}

1. Santé Publique France. Enquête Nationale de Prévalence des Infections Nosocomiales et Des Traitements Anti-Infectieux en Établissements de Santé, Mai-Juin 2017; Santé Publique France: Saint Maurice, France, 2018; pp. 1-12.

2. Schweizer, H.P. Mechanisms of antibiotic resistance in Burkholderia pseudomallei: Implications for treatment of melioidosis. Future Microbiol. 2012, 7, 1389-1399. [CrossRef] [PubMed]

3. Inglis, T.J.J.; Rolim, D.B.; Sousa, A.D.Q. Melioidosis in the Americas. Am. J. Trop. Med. Hyg. 2006, 75, 947-954. [CrossRef] [PubMed]

4. Benoit, T.J.; Elrod, M.G.; Walke, H.T.; Inglis, T.J.J.; Bower, W.A.; Gee, J.E.; Doker, T.J.; Hoffmaster, A.R.; Rolim, D.B.; Blaney, D.D. A review of melioidosis cases in the Americas. Am. J. Trop. Med. Hyg. 2015, 93, 1134-1139. [CrossRef] [PubMed]

5. Limmathurotsakul, D.; Golding, N.; Dance, D.A.B.; Messina, J.P.; Pigott, D.M.; Moyes, C.L.; Rolim, D.B.; Bertherat, E.; Day, N.P.J.; Peacock, S.J.; et al. Predicted global distribution of Burkholderia pseudomallei and burden of melioidosis. Nat. Microbiol. 2016, 1, 1-5. [CrossRef] [PubMed]

6. Mislin, G.L.A.; Schalk, I.J. Siderophore-dependent iron uptake systems as gates for antibiotic Trojan horse strategies against Pseudomonas aeruginosa. Metallomics 2014, 6, 408-420. [CrossRef] [PubMed]

7. Pham, T.; Loupias, P.; Dassonville-Klimpt, A.; Sonnet, P. Drug delivery systems designed to overcome antimicrobial resistance. Med. Res. Rev. 2019, 1-54. [CrossRef] [PubMed]

8. Neilands, J.B. Iron absorption and transport in microorganisms. Annu. Rev. Nutr. 1981, 1, 27-46. [CrossRef]

9. Ratledge, C. Iron metabolism and infection. Food Nutr. Bull. 2007, 28, S515-S523. [CrossRef] 
10. Pollack, J.R.; Neilands, J.B. Enterobactin, an iron transport compound from Salmonella Typhimurium. Biochem. Biophys. Res. Commun. 1970, 38, 4. [CrossRef]

11. Neilands, J.B. Siderophores: Structure and function of microbial iron transport compounds. J. Biol. Chem. 1995, 270, 26723-26726. [CrossRef]

12. Braun, V.; Killmann, H. Bacterial solutions to the iron-supply problem. Trends Biochem. Sci. 1999, 24, 104-109. [CrossRef]

13. Hider, R.C.; Kong, X. Chemistry and biology of siderophores. Nat. Prod. Rep. 2010, 27, 637-657. [CrossRef] [PubMed]

14. Nader, M.; Journet, L.; Meksem, A.; Guillon, L.; Schalk, I.J. Mechanism of ferripyoverdine uptake by Pseudomonas aeruginosa outer membrane transporter FpvA: No diffusion channel formed at any time during ferrisiderophore uptake. Biochemistry 2011, 50, 2530-2540. [CrossRef] [PubMed]

15. Valappil, S.P.; Yiu, H.H.P.; Bouffier, L.; Hope, C.K.; Evans, G.; Claridge, J.B.; Higham, S.M.; Rosseinsky, M.J. Effect of novel antibacterial gallium-carboxymethyl cellulose on Pseudomonas aeruginosa. Dalton Trans. 2013, 42, 1778-1786. [CrossRef]

16. Page, M.G.P.; Dantier, C.; Desarbre, E. In vitro properties of BAL30072, a novel siderophore sulfactam with activity against multiresistant Gram-Negative bacilli. Antimicrob. Agents Chemother. 2010, 54, 2291-2302. [CrossRef]

17. Schell, M.A.; Zhao, P.; Wells, L. Outer membrane proteome of Burkholderia pseudomallei and Burkholderia mallei from diverse growth conditions. J. Proteome Res. 2011, 10, 2417-2424. [CrossRef]

18. Mima, T.; Kvitko, B.H.; Rholl, D.A.; Page, M.G.P.; Desarbre, E.; Schweizer, H.P. In vitro activity of BAL30072 against Burkholderia pseudomallei. Int. J. Antimicrob. Agents 2011, 38, 157-159. [CrossRef]

19. Luscher, A.; Moynié, L.; Auguste, P.S.; Bumann, D.; Mazza, L.; Pletzer, D.; Naismith, J.H.; Köhler, T. TonB-dependent receptor repertoire of Pseudomonas aeruginosa for uptake of siderophore-drug conjugates. Antimicrob. Agents Chemother. 2018, 62, 1-11. [CrossRef]

20. Portsmouth, S.; van Veenhuyzen, D.; Echols, R.; Machida, M.; Ferreira, J.C.A.; Ariyasu, M.; Tenke, P.; Nagata, T.D. Cefiderocol versus imipenem-cilastatin for the treatment of complicated urinary tract infections caused by Gram-negative uropathogens: A phase 2, randomised, double-blind, non-inferiority trial. Lancet Infect. Dis. 2018, 18, 1319-1328. [CrossRef]

21. Ito, A.; Sato, T.; Ota, M.; Takemura, M.; Nishikawa, T.; Toba, S.; Kohira, N.; Miyagawa, S.; Ishibashi, N.; Matsumoto, S.; et al. In vitro antibacterial properties of cefiderocol, a novel siderophore cephalosporin, against Gram-Negative bacteria. Antimicrob. Agents Chemother. 2018, 62, 1-11. [CrossRef]

22. Fardeau, S.; Dassonville-Klimpt, A.; Audic, N.; Sasaki, A.; Pillon, M.; Baudrin, E.; Mullié, C.; Sonnet, P. Synthesis and antibacterial activity of catecholate-Ciprofloxacin conjugates. Bioorg. Med. Chem. 2014, 22, 4049-4060. [CrossRef] [PubMed]

23. Antonietti, V.; Boudesocque, S.; Dupont, L.; Farvacques, N.; Cézard, C.; Da Nascimento, S.; Raimbert, J.F.; Socrier, L.; Robin, T.J.; Morandat, S.; et al. Synthesis, iron(III) complexation properties, molecular dynamics simulations and P. aeruginosa siderophore-like activity of two pyoverdine analogs. Eur. J. Med. Chem. 2017, 137, 338-350. [CrossRef] [PubMed]

24. Rathi, A.K.; Syed, R.; Shin, H.S.; Patel, R.V. Piperazine derivatives for therapeutic use: A patent review (2010-present). Expert Opin. Ther. Pat. 2016, 26, 777-797. [CrossRef] [PubMed]

25. Magotra, A. Physicochemical, pharmacokinetic, efficacy and toxicity profiling of a potential nitrofuranyl methyl piperazine derivative IIIM-MCD-211 for oral tuberculosis therapy via in-silico-in-vitro-in-vivo approach. Pulm. Pharmacol. Ther. 2018, 48, 151-160. [CrossRef]

26. Kharb, R.; Bansal, K.; Sharma, A.K. A valuable insight into recent advances on antimicrobial activity of piperazine derivatives. Pharma Chem. 2012, 4, 2470-2488.

27. Schiller, D.; Fung, H. Posaconazole: An extended-spectrum triazole antifungal agent. Clin. Ther. 2007, 29, 1862-1886. [CrossRef] [PubMed]

28. Kern, W.V.; Steinke, P.; Schumacher, A.; Schuster, S. Effect of 1-(1-naphthylmethyl)-piperazine, a novel putative efflux pump inhibitor, on antimicrobial drug susceptibility in clinical isolates of Escherichia coli. J. Antimicrob. Chemother. 2006, 57, 339-343. [CrossRef]

29. Leite, A.; Silva, A.M.G.; Nunes, A.; Andrade, M.; Sousa, C.; Cunha-Silva, L.; Gameiro, P.; de Castro, B.; Rangel, M. Novel tetradentate chelators derived from 3-hydroxy-4-pyridinone units: Synthesis, characterization and aqueous solution properties. Tetrahedron 2011, 67, 4009-4016. [CrossRef] 
30. Gao, J.; Xing, F.; Bai, Y.; Zhu, S. Synthesis, spectroscopy, and binding constants of ketocatechol-containing iminodiacetic acid and its $\mathrm{Fe}(\mathrm{III}), \mathrm{Cu}(\mathrm{II})$, and $\mathrm{Zn}(\mathrm{II})$ complexes and reaction of $\mathrm{Cu}$ (II) complex with $\mathrm{H}_{2} \mathrm{O}_{2}$ in aqueous solution. Dalton Trans. 2014, 43, 7964-7978. [CrossRef]

31. Allam, A.; Dechamps-Olivier, I.; Behr, J.B.; Dupont, L.; Plantier-Royon, R. Thermodynamic, spectroscopic studies and catechol oxidase activity of copper (II) complexes with amphiphilic $d$-galacturonic acid derived ligands. Inorg. Chim. Acta 2011, 366, 310-319. [CrossRef]

32. Nurchi, V.M.; Crisponi, G.; Pivetta, T.; Donatoni, M.; Remelli, M. Potentiometric, spectrophotometric and calorimetric study on iron(III) and copper(II) complexes with 1,2-dimethyl-3-hydroxy-4-pyridinone. J. Inorg. Biochem. 2008, 102, 684-692. [CrossRef] [PubMed]

33. Charkoudian, L.K.; Franz, K.J. Fe(III)-coordination properties of neuromelanin components: 5,6-dihydroxyindole and 5,6-dihydroxyindole-2-carboxylic acid. Inorg. Chem. 2006, 45, 3657-3664. [CrossRef] [PubMed]

34. Elhabiri, M.; Carrër, C.; Marmolle, F.; Traboulsi, H. Complexation of iron(III) by catecholate-type polyphenols. Inorg. Chim. Acta 2007, 360, 353-359. [CrossRef]

35. Miethke, M.; Marahiel, M.A. Siderophore-based iron acquisition and pathogen control. Microbiol. Mol. Biol. Rev. 2007, 71, 413-451. [CrossRef] [PubMed]

36. Cézard, C.; Farvacques, N.; Sonnet, P. Chemistry and biology of pyoverdines, Pseudomonas primary siderophores. Curr. Med. Chem. 2015, 22, 165-186. [CrossRef] [PubMed]

37. Albrecht-Gary, A.M.; Blanc, S.; Rochel, N.; Ocaktan, A.Z.; Abdallah, M.A. Bacterial iron transport: Coordination properties of pyoverdin PaA, a peptidic siderophore of Pseudomonas aeruginosa. Inorg. Chem. 1994, 33, 6391-6402. [CrossRef]

38. Clinical and Laboratory Standards Institute (Ed.) Methods for Dilution Antimicrobial Susceptibility Tests for Bacteria That Grow Aerobically: M07-A10; Approved Standard; Committee for Clinical Laboratory Standards: Wayne, PA, USA, 2015; ISBN 978-1-56238-987-1.

39. Takase, H.; Nitanai, H.; Hoshino, K.; Otani, T. Impact of siderophore production on Pseudomonas aeruginosa infections in immunosuppressed mice. Infect. Immun. 2000, 68, 1834-1839. [CrossRef]

40. Meyer, J.M.; Abdallah, M.A. The fluorescent pigment of Pseudomonas fluorescens: Biosynthesis, purification and physicochemical properties. J. Gen. Microbiol. 1978, 107, 319-328. [CrossRef]

41. Bergeron, R.J.; Bharti, N.; Singh, S.; McManis, J.S.; Wiegand, J.; Green, L.G. Vibriobactin antibodies: A vaccine strategy. J. Med. Chem. 2009, 52, 3801-3813. [CrossRef]

42. Senko, M. Isopro 3.0 MS/MS Software; National High Magnetic Field Laboratory: Sunnyvale, CA, USA, 2017.

43. Fournaise, R.; Petitfaux, C. Etude de la formation des complexes en solution aqueuse-III Nouvelle méthode $\mathrm{d}$ 'affinement des constantes de stabilité des complexes et des autres paramètres des titrages protométriques. Talanta 1987, 34, 385-395. [CrossRef]

44. Gans, P.; Sabatini, A.; Vacca, A. Investigation of equilibria in solution. Determination of equilibrium constants with the HYPERQUAD suite of programs. Talanta 1996, 43, 1739-1753. [CrossRef]

45. Alderighi, L.; Gans, P.; Ienco, A.; Peters, D.; Sabatini, A.; Vacca, A. Hyperquad simulation and speciation (HySS): A utility program for the investigation of equilibria involving soluble and partially soluble species. Coord. Chem. Rev. 1999, 184, 311-318. [CrossRef]

46. Steinhauser, S.; Heinz, U.; Bartholomä, M.; Weyhermüller, T.; Nick, H.; Hegetschweiler, K. Complex formation of ICL670 and related ligands with Fe(III) and Fe(II). Eur. J. Inorg. Chem. 2004, 2004, 4177-4192. [CrossRef]

47. Rouge, P.; Dassonville-Klimpt, A.; Cézard, C.; Boudesocque, S.; Ourouda, R.; Amant, C.; Gaboriau, F.; Forfar, I.; Guillon, J.; Guillon, E.; et al. Synthesis, physicochemical studies, molecular dynamics simulations, and metal-ion-dependent antiproliferative and antiangiogenic properties of cone ICL670-substituted calix [4] arenes. ChemPlusChem 2012, 77, 1001-1016. [CrossRef] [PubMed]

48. Lowry, R. Mann-Whitney Test. Available online: http://vassarstats.net (accessed on 17 October 2019).

(C) 2019 by the authors. Licensee MDPI, Basel, Switzerland. This article is an open access article distributed under the terms and conditions of the Creative Commons Attribution (CC BY) license (http://creativecommons.org/licenses/by/4.0/). 